OPEN ACCESS

Edited by:

Rudolf Bauer,

University of Graz, Austria

Reviewed by:

Liselotte Krenn,

Universität Wien, Austria

Wesam Kooti,

Kurdistan University of Medical

Sciences, Iran

${ }^{*}$ Correspondence:

Yu Zhang

262730291@qq.com

Jiyu Zhang

shangxf928@126.com

Specialty section:

This article was submitted to

Ethnopharmacology,

a section of the journal

Frontiers in Pharmacology

Received: 11 June 2018 Accepted: 10 January 2019 Published: 04 February 2019

Citation:

Shang $X$, Miao $X$, Yang $F$, Wang C, Li B, Wang W, Pan H, Guo X, Zhang Y and Zhang J (2019)

The Genus Adonis as an Important Cardiac Folk Medicine: A Review of the Ethnobotany, Phytochemistry and Pharmacology.

Front. Pharmacol. 10:25. doi: 10.3389/fphar.2019.00025

\section{The Genus Adonis as an Important Cardiac Folk Medicine: A Review of the Ethnobotany, Phytochemistry and Pharmacology}

\author{
Xiaofei Shang 1,2, Xiaolou Miao ${ }^{1,2}$, Feng Yang ${ }^{1,2}$, Chunmei Wang ${ }^{1,2}$, Bing Li ${ }^{1,2}$, \\ Weiwei Wang ${ }^{1,2}$, Hu Pan ${ }^{1,2}$, Xiao Guo ${ }^{3}$, Yu Zhang ${ }^{4 *}$ and Jiyu Zhang ${ }^{1,2 *}$
}

${ }^{1}$ Key Laboratory of New Animal Drug Project, Lanzhou Institute of Husbandry and Pharmaceutical Sciences, Chinese Academy of Agricultural Sciences, Lanzhou, China, ${ }^{2}$ Key Laboratory of Veterinary Pharmaceutical Development of Ministry of Agriculture, Lanzhou Institute of Husbandry and Pharmaceutical Sciences, Chinese Academy of Agricultural Sciences, Lanzhou, China, ${ }^{3}$ Tibetan Medicine Research Center, Qinghai University Medical College, Qinghai University, Xining, China, ${ }^{4}$ PLA Lanzhou General Hospital, Lanzhou, China

The genus Adonis L. (Ranunculaceae), native to Europe and Asia, comprises 32 annual or perennial herbaceous species. Due to their cardiac-enhancing effects, Adonis spp. have long been used in European and Chinese folk medicine. These plants have been widely investigated since the late 19th century, when the cardiovascular activity of Adonis vernalis L. was noted in Europe. The present paper provides a review of the phytochemistry, biological activities and toxicology in order to highlight the future prospects of the genus. More than 120 chemical compounds have been isolated, with the most important components being cardiac glycosides as well as flavones, carotenoids, coumarins and other structural types. Plants of the genus, especially $A$. vernalis $L$. and $A$. amurensis Regel \& Radde, their extracts and their active constituents possess broad pharmacological properties, including cardiovascular, antiangiogenic, antibacterial, antioxidant, anti-inflammatory and acaricidal activities, and exhibit both diuretic effects and effects on the central nervous system. However, most plants within the 32 species have not been comprehensively studied, and further clinical evaluation of their cardiovascular activity and toxicity should be conducted after addressing the problem of the rapidly decreasing resources. This review provides new insight into the genus and lays a solid foundation for further development of Adonis.

Keywords: Adonis L., cardiac glycosides, cardiovascular activity, toxicity, resources

\section{INTRODUCTION}

The genus Adonis L. (Ranunculaceae), native to Europe and Asia, comprises 32 annual or perennial herbaceous species and grows in temperate regions of the northern hemisphere (Ghorbani et al., 2008; Orhan et al., 2017). The genus was named after the Greek mythological character, and Adonis spp. have long been used in European and Chinese folk medicine for their cardiac-enhancing effects (Abduchamidov et al., 1971; Felter and Lloyd, 2006). Due to the marked effects on heart disease, researchers began focusing attention on the genus Adonis (Shikov et al., 2014). With advancements in phytochemistry research, greater numbers of compounds were isolated from 
the plants of this genus (Heyl et al., 1918); the compounds exhibiting significant cardiovascular activity were primarily classified as cardiac glycosides (Katz and Reichstein, 1947; Deng et al., 1963; Chi et al., 1985). These reports further substantiated the traditional uses of these plants for cardiac enhancement (Shikov et al., 2014). Moreover, flavones, carotenoids, coumarins and other structural classes were identified, and additional pharmacological activities were found, including antiangiogenic, antibacterial, antioxidant and anti-inflammatory activities, as well as effects on the central nervous system, a diuretic effect and acaricidal activity (May and Willuhn, 1978; Gu et al., 1980; Wang et al., 1981; You et al., 2003; Das et al., 2007; Shang et al., 2012, 2013, 2017; Mohadjerani et al., 2014). These newly discovered compounds and their previously unknown bioactivities advanced and promoted the development of the genus Adonis (Yang et al., 2015).

In the late 19th century, the cardiovascular activity of Adonis vernalis $\mathrm{L}$. distributed in the Eurasian region was observed. And since the early 20th century, extracts of this plant enriched in cardiac glycosides were prepared to treat chronic heart failure in the former Soviet Union and Germany. In China and other East Asian countries including Korea, and Japan, A. amurensis Regel \& Radde was studied and used to treat heart diseases in the mid-20th century due to a shortage of cardiotonic agents (Deng et al., 1963). Additionally, the toxicity of these plants became apparent, and Adonis-induced poisoning cases in both humans and animals were observed (Hurst, 1942; Galey et al., 1996; Woods et al., 2004).

Until recently, researchers have made great advances in studying the phytochemical and pharmacological activities of genus Adonis. However, no review article discussing these achievements is available in the literature. This review strives for a complete overview of the existing botanical knowledge, traditional uses, phytochemistry and pharmacological research of species belonging to the genus Adonis. Available information on these species enables us to explore their therapeutic potential, to highlight the gaps in our knowledge and to provide the scientific basis for future research.

\section{METHODS}

As well as two reviews published by Kooti et al. (2016, 2018), in this review we searched the information on this genus from databases (using Elsevier, ACS, Springer, Wiley, Nature, RSC, Medline Plus, Bentham Science, Hindawi Science, CNKI, VIP, Web of Science, Google Scholar and Baidu Scholar) and libraries, and the search languages were set to English and Chinese. We didn't set the time period for searching more literatures. The keywords were searched as Adonis for English literatures, Cejinzhan (侧金笽) and/or Fushoucao (福寿草) for Chinese literatures. Three experts collected the literatures.

\section{BOTANY}

The generic name Adonis refers to the mythic character Adonis, a lover of the goddess Aphrodite or Venus. Plants belonging to the Adonis genus are native to Europe and Asia and have been introduced to North America. It includes approximately 32 annual or perennial herbaceous species of flowering plants of Ranunculaceae. In “The Plant List," 143 scientific plant names of species rank for the genus Adonis are included, and of these 32 are accepted species names (The plant list, 2013). Basal and lower stem leaves are usually scaly and upper stem leaves alternate and are palmately or pinnately divided. One-flowered inflorescences terminate on branches or branchlets with absent bracts. The flowers are radially symmetric, bisexual and usually red, orange, or yellowish, having 5 to 30 petals. The plants possess numerous stamens and spirally arranged pistils, linear filaments, and one-ovuled ovaries with persistent styles and small stigma. The plants have achenes, usually with raised veins, and the leaves and roots are poisonous to humans and livestock (Heyn and Pazy, 1989; Gostin, 2011; Flora of China, 2018). Due to the beauty of the flower, the plants of this genus were used historically for ornamental purposes in some countries. Only in Germany, the former Soviet Union and some East Asian countries some species and their extracts were used as cardiac agents, especially A. vernalis and $A$. amurensis (Table 1 and Figure 1).

\section{TRADITIONAL USES}

Adonis vernalis, known as the Bird's eye, Pheasant's eye or False Hellebore, is a perennial, dry grassland plant species distributed in the Eurasian region along a 4698-km longitudinal transect from Russia to Spain (Hirsch et al., 2015). This species prefers calcium-rich chernozem soils of various types but also grows in meadow chernozems and gray forest soils (Poluyanova and Lyubarskii, 2008). It is listed in the German Homoeopathic Pharmacopoeia (Shikov et al., 2014). Historically, it was used to treat edema by local people of the former Soviet Union. Extracts of the plant were first introduced into medicine as a cardiac stimulant in 1879 by the Russian medical doctor, N. O. Buhnow, and $A$. vernalis has attracted the interest of many people ever since. In 1898, a mixture of this medicine with sodium bromide (or potassium bromide) or codeine was suggested to treat light forms of epilepsy and heart diseases (Bekhterev, 1898; Shikov et al., 2014). Over the intervening years, an ethanolic extract of the aerial parts of $A$. vernalis was prepared as an alternative cardiac agent in the former Soviet Union. The biological activity of this extract was defined as 50-66 frog units or 6.3-8.0 cat units (Chiang and Mi, 1958; Wagler, 2001). Now, in Russia, the aerial part as a cardiotonic, was applied in the clinics for internal use at the dose of 1 tablespoon of the infusion (7:200) 3-5 times per day (Sokolov et al., 2000; Shikov et al., 2014).

Ten species are distributed in China. One thousand years ago, plants belonging to the Adonis genus in China (Chinese name: Binglianghua or Fushoucao) were recorded in the ancient book "Gui Hai Yu Heng Zhi" written by Fan Chengda, a notable historical figure from the Song dynasty. The well-known classical book of Chinese materia medica, "Ben Cao Gang Mu," also noted the effect (Keshan Research Group of Jilin Medical University, First Clinical College, Second Clinical College, Third Clinical College of Jilin Medical University, 1977), and raw materials have 
TABLE 1 | The accepted plant names by The Plant List*.

\begin{tabular}{|c|c|c|c|c|}
\hline Name & Distribution & Traditional uses & Others & Reference \\
\hline Adonis aestivalis $\mathrm{L}$. & $\begin{array}{l}\text { Native to Europe and Asia, was } \\
\text { introduced into North America }\end{array}$ & $\begin{array}{l}\text { Medicinal and ornamental } \\
\text { plant }\end{array}$ & $\begin{array}{l}\text { Stems } 10-20 \mathrm{~cm} \text { tall. Sepals narrowly rhombic } \\
\text { to narrowly ovate, membranous. Petals orange. }\end{array}$ & Burrows and Tyrl, 2001 \\
\hline $\begin{array}{l}\text { Adonis amurensis } \\
\text { Regel \& Radde }\end{array}$ & $\begin{array}{l}\text { Native to Japan, Russia, Korea, } \\
\text { and China }\end{array}$ & Medicinal plant & $\begin{array}{l}\text { Stems } 5-15 \mathrm{~cm} \text { tall in flower, to } 30 \mathrm{~cm} \text { tall in } \\
\text { fruit. Flowers } 2.8-3.5 \mathrm{~cm} \text { in diameter, sepals } \\
\text { pale grayish purple, Petals yellow. }\end{array}$ & $\begin{array}{l}\text { Shimizu et al., 1967; } \\
\text { Flora of China, } 2018 .\end{array}$ \\
\hline Adonis annua L. & $\begin{array}{l}\text { Native to North Africa, Western } \\
\text { Asia, the Mediterranean, } \\
\text { Europe }\end{array}$ & - & $\begin{array}{l}\text { It is endangered and listed as a priority species } \\
\text { in United Kingdom }\end{array}$ & Egger, 1965 \\
\hline $\begin{array}{l}\text { Adonis bobroviana } \\
\text { Simonov. }\end{array}$ & Native to China & - & $\begin{array}{l}\text { Stems to } 30 \mathrm{~cm} \text { tall. Flowers } 2-4 \mathrm{~cm} \text { in } \\
\text { diameter Sepals pale green tinged with purple, } \\
\text { Petals yellow, abaxially tinged with purple. }\end{array}$ & Flora of China, 2018 \\
\hline $\begin{array}{l}\text { Adonis } \\
\text { chrysocyathus } \\
\text { Hook.f. \& Thomson }\end{array}$ & $\begin{array}{l}\text { Native to Greek, and cultivated } \\
\text { in the botanical gardens of } \\
\text { Copenhagen or Gothenburg }\end{array}$ & - & $\begin{array}{l}\text { Heights from } 203 \text { to } 381 \mathrm{~mm} \text {. Orange or yellow } \\
\text { flowers. Flower color is variable within the } \\
\text { species and changes with drying. }\end{array}$ & Heyn and Pazy, 1989 \\
\hline $\begin{array}{l}\text { Adonis coerulea } \\
\text { Maxim. }\end{array}$ & Native to China & Treating mange & $\begin{array}{l}\text { Stems 3-15 cm tall. Flowers } 1-1.8 \mathrm{~cm} \text { in } \\
\text { diameter Sepals obovate-elliptic to ovate, apex } \\
\text { rounded. Petals ca. 8, pale purple to pale blue. }\end{array}$ & $\begin{array}{l}\text { Shang et al., 2013; } \\
\text { Flora of China, } 2018\end{array}$ \\
\hline $\begin{array}{l}\text { Adonis davidii } \\
\text { Franch. }\end{array}$ & Native to China and Bhutan & - & $\begin{array}{l}\text { Stems } 10-58 \mathrm{~cm} \text { tall. Stem leaves with petiole } \\
\text { to } 7 \mathrm{~cm} \text { basally on stem, shortly petiolate or } \\
\text { sessile toward stem apex; flowers } 1.5-2.8 \mathrm{~cm} \\
\text { in diameter Sepals glabrous, rarely ciliate. } \\
\text { Petals white, sometimes tinged with purple. }\end{array}$ & Flora of China, 2018. \\
\hline $\begin{array}{l}\text { Adonis flammea } \\
\text { Jacq. }\end{array}$ & $\begin{array}{l}\text { Distributes in the Anatolia, the } \\
\text { Levant Central and Southern } \\
\text { Europe }\end{array}$ & - & $\begin{array}{l}\text { It is similar to } A \text {. annua but is more robust with } \\
\text { large flowers with narrow and oblong petals, } \\
\text { dark scarlet sepals that are attached to the } \\
\text { petals. }\end{array}$ & Catalogue of Life, 2017 \\
\hline $\begin{array}{l}\text { Adonis microcarpa } \\
\text { DC. }\end{array}$ & $\begin{array}{l}\text { Native to western Asia and } \\
\text { southern Europe and is } \\
\text { introduced in Australia }\end{array}$ & - & $\begin{array}{l}50 \mathrm{~cm} \text { tall, has finely divided foliage and red } \\
\text { flowers with black centers. }\end{array}$ & Kloot, 1976 \\
\hline $\begin{array}{l}\text { Adonis multiflora } \\
\text { Nishikawa \& Koji Ito }\end{array}$ & $\begin{array}{l}\text { Native to Korea, Japan, and } \\
\text { Manchuria }\end{array}$ & Ornamental plant & $\begin{array}{l}20-25 \mathrm{~cm} \text { tall at flowering with up to four yellow } \\
\text { flowers per stem. }\end{array}$ & Lee et al., 2003 \\
\hline $\begin{array}{l}\text { Adonis ramosa } \\
\text { Franch. }\end{array}$ & $\begin{array}{l}\text { Native to Japan, Russia, Korea, } \\
\text { and China }\end{array}$ & - & $\begin{array}{l}\text { Stems } 4-20 \mathrm{~cm} \text { tall, } 1.2-2 \mathrm{~mm} \text { in diameter } \\
\text { Flowers } 2.5-4 \mathrm{~cm} \text { in diameter Sepals } \\
\text { gray-purple. Petals yellow. }\end{array}$ & Flora of China, 2018 \\
\hline $\begin{array}{l}\text { Adonis } \\
\text { shikokuensis } \\
\text { Nishikawa \& Koji } \\
\text { Ito. Or Adonis } \\
\text { sibirica (Patrin ex } \\
\text { DC.) Ledeb. }\end{array}$ & $\begin{array}{l}\text { Native to Mongolia, Russia; } \\
\text { Europe and China }\end{array}$ & Medicinal uses & $\begin{array}{l}\text { Stems ca. } 40 \mathrm{~cm} \text { tall, } 3-5 \mathrm{~mm} \text { in diameter } \\
\text { Sepals yellowish green, rounded-ovate. Petals } \\
\text { yellow, narrowly obovate. }\end{array}$ & Flora of China, 2018 \\
\hline $\begin{array}{l}\text { Adonis } \\
\text { sutchuenensis } \\
\text { Franch. }\end{array}$ & Native to China & - & $\begin{array}{l}\text { Stems } 15-40 \mathrm{~cm} \text { tall, Flowers } 2-4.8 \mathrm{~cm} \text { in } \\
\text { diameter Sepals pale green, usually } \\
\text { oblanceolat. Petals yellow, }\end{array}$ & Flora of China, 2018 \\
\hline $\begin{array}{l}\text { Adonis } \\
\text { tianschanica (Adolf) } \\
\text { Lipsch. }\end{array}$ & Native to Russia and China & - & $\begin{array}{l}\text { Stems ca. } 30 \mathrm{~cm} \text { tall. Flowers } 3.5-5 \mathrm{~cm} \text { in } \\
\text { diameter Sepals pale purple, slightly shorter } \\
\text { than petals. }\end{array}$ & Flora of China, 2018 \\
\hline Adonis vernalis L. & $\begin{array}{l}\text { Natively in central Europe and } \\
\text { in Asia }\end{array}$ & $\begin{array}{l}\text { Cardiac stimulant and } \\
\text { ornamental plant }\end{array}$ & $\begin{array}{l}\text { The flowers appear in springtime, and are up to } \\
80 \mathrm{~mm} \text { in diameter, with up to } 20 \text { bright yellow } \\
\text { petals }\end{array}$ & Heyl et al., 1918 \\
\hline
\end{tabular}

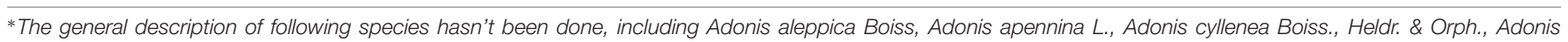

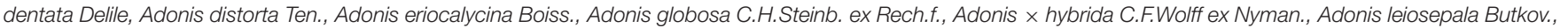

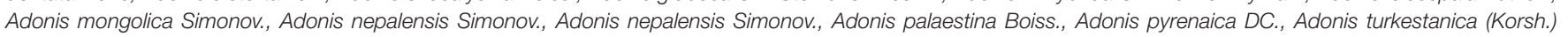
Adolf., Adonis villosa Ledeb., Adonis volgensis Steven ex DC., Adonis wolgensis Steven.

been used in folk medicine for the treatment of heart diseases and edema (Bae, 2000). During the 1950s, due to the shortage of cardiac agents, Adonis sp. distributed throughout China were widely studied and developed. These efforts resulted in the isolation and further study of the cardenolide-enriched extracts of A. amurensis. After comprehensive pharmacological tests, the extracts were prepared and developed in a new preparation that was used to clinically treat human heart failure (Coronary Disease Control Group of Liaoning TCM College's Hospital, 1971). In 1975, the raw material of this plant was listed in the Pharmacopeia of the People's Republic of China (Committee for the Pharmacopoeia of P. R. China, 1975). In Siberia, the aqueous 


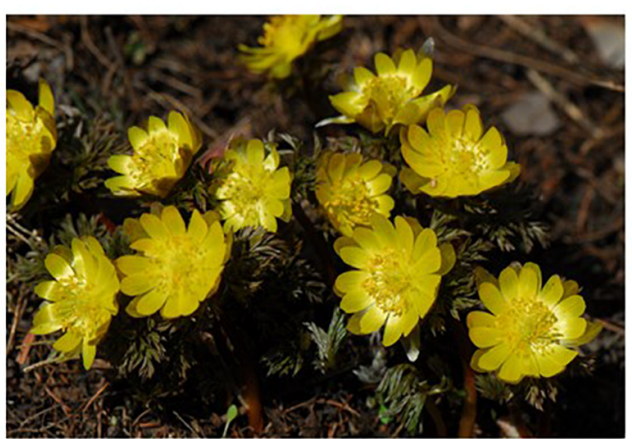

Adonis amurensis Regel et Radde

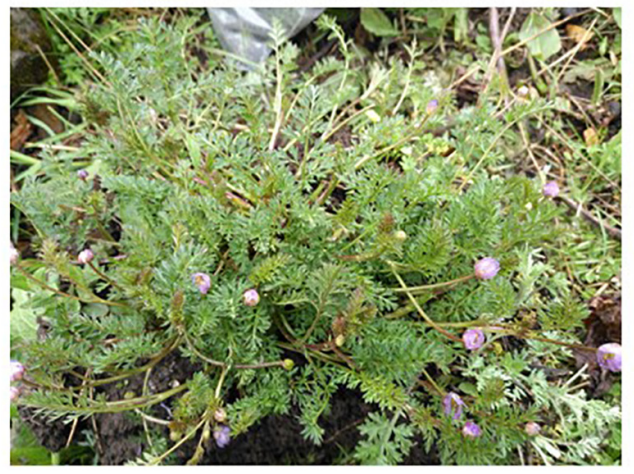

Adonis coerulea Maxim.

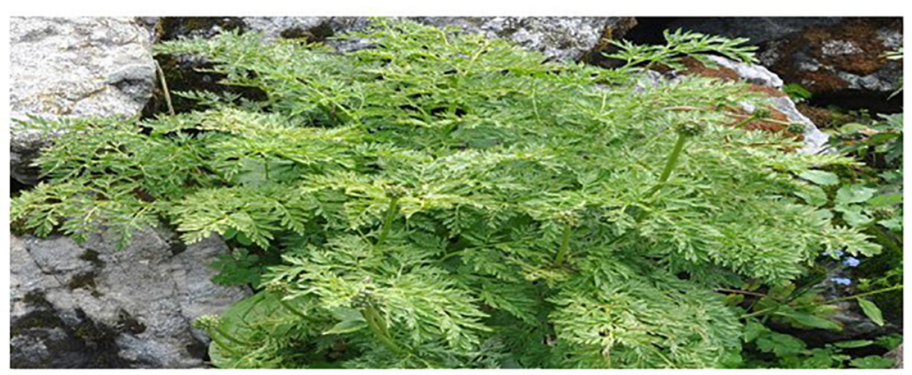

Adonis chrysocyathus Hook.f. \& Thomson

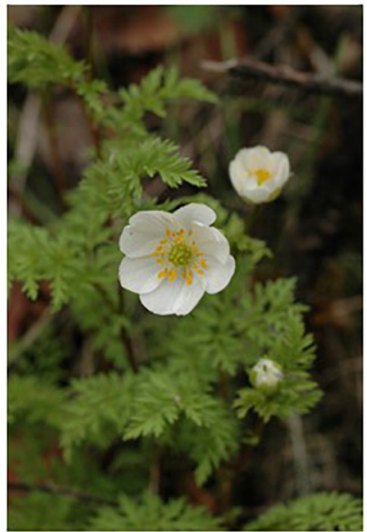

Adonis davidii Franchet



Adonis aestivalis L.

FIGURE 1 | The pictures of five plants grown in China.

extract of the aerial parts was used to treat malaria, kidney disease and other heart-related diseases (Utkin, 1931; Nosal and Nosal, 1960).

\section{PHYTOCHEMISTRY}

Since the first compound was isolated from Adonis plants in the early 19th century, more than 120 compounds have been isolated and identified to date. Fifty-four cardiac glycoside compounds were identified as active components. Additionally, flavones, carotenoids, coumarins and other compounds were also isolated and reported (Table 2). The chemical structures of active compounds isolated from the genus Adonis were listed in Figure 2.

\section{Cardiac Glycosides and Other Glycosides Cardiac Glycosides}

Cardiac glycosides are important active compounds of the genus Adonis. Since the extract of $A$. vernalis was introduced into medicine in 1879 , the increasing numbers of compounds have been isolated and identified. In 1918, a method for the preparation of an active digitalis-like glucoside from $A$. vernalis was developed (Heyl et al., 1918). Cymarin (1), adonitoxin (2), 16-hydroxy-strophanthidin (3), acetyladonitoxin (4), vernadigin (5) and 3-acetylstrophadogenin (6) were subsequently isolated
(Katz and Reichstein, 1947; Pitra and Čekan, 1961; Poláková and Čekan, 1965). In 1965, a new glycoside, substance N (7), was isolated from the leaves of $A$. vernalis (Büchner et al., 1965). Additional isolated compounds include strophanthidine fucoside (8), 3-epi-periplogenin (9), 17 $\beta-\left(2^{\prime}, 5^{\prime}\right.$-dihydro- $5^{\prime}$ oxo- $3^{\prime}$-furyl)- $5 \beta$-14 $\beta$-androstane- $3 \alpha, 5 \beta, 14 \beta$-triol (10), adonit oxigenin 2-O-acetylrhamnosidoxyloside (11), adonitoxigenin 3-O-acetylrhamnosidoxyloside (12), adonitoxigenin rhamnosid oxyloside (13) and cymarin (Franz, 1971; Wichtl et al., 1972; Mathe and Mathe, 1979a,b; Junior and Wichtl, 1980; Winkler and Wichtl, 1985). Adonitoxigenin 3-O-[ $\beta$-D-glucopyranosyl- $(1 \rightarrow 4)-\alpha$-L-rhamno pyranoside (14), adonitoxigenin 3-O-[ $\beta$-D-glucopyranosyl$(1 \rightarrow 4)-\alpha$-L-(3'-O-acetyl)-rhamnopyranoside (15), adonit oxigenin-3-[O- $\alpha$-L $\left(2^{\prime}-O\right.$-acetyl $)$ rhamnosido- $\beta$-D-glucoside (16) and $17 \beta-\left(2^{\prime}, 5^{\prime}\right.$-dihydro- $5^{\prime}$-oxo- $3^{\prime}$-furyl $)-5 \beta-14 \beta$-androstane- $3 \alpha$, $5 \beta, 14 \beta$-triol (17) were also identified (Junior and Wichtl, 1980; Winkler and Wichtl, 1986).

Adonis aleppica is endemic in Mesopotamia and southeastern Anatolia and is closely related to A. vernalis, which is used as a heart tonic. In 1985, 3-epi-periplogenine, periplorhamnoside (18) and strophanthidin-diginoside (19) were isolated (Junior and Wichtl, 1980). Subsequently, the first cardenolidesulfate uzarigenin-3-O-sulfate (20) was identified, along with alepposides A (21), B (22), C (23), and D (24); sarmentocymarin (25); and a glycosidic conjugate named aleppotrioloside (26) that were also isolated from the whole 
TABLE 2 | The isolated compounds from the genus Adonis.

\begin{tabular}{|c|c|c|c|}
\hline No. & Compounds & Species & Reference \\
\hline (1) & Cymarin & $\begin{array}{l}\text { A. vernalis } \\
\text { A. amurensis } \\
\text { A. wolgensis } \\
\text { A. chrysocyathus } \\
\text { A. tianschanicus } \\
\text { A. turkestanicus } \\
\text { A. leiosepala } \\
\text { A. mongolica } \\
\text { A. pseudoamurensis }\end{array}$ & $\begin{array}{l}\text { Katz and Reichstein, 1947; } \\
\text { Ponomarenko et al., 1971a; Genkina } \\
\text { et al., 1972; Komissarenko et al., } \\
\text { 1973a,b,c, 1977; Lamzhav, 1975; } \\
\text { Evdokimov, 1979; Ma et al., 1985; You } \\
\text { et al., 2003; Yin et al., } 2014\end{array}$ \\
\hline (2) & Adonitoxin & $\begin{array}{l}\text { A. vernalis } \\
\text { A. chrysocyathus } \\
\text { A. mongolica }\end{array}$ & $\begin{array}{l}\text { Katz and Reichstein, 1947; Lamzhav, } \\
\text { 1975; Yatsyuk et al., } 1976\end{array}$ \\
\hline (3) & 16-Hydroxy-strophanthidin & A. vernalis & Pitra and Čekan, 1961 \\
\hline (8) & Strophanthidine fucoside & A. vernalis & Wichtl et al., 1972 \\
\hline (9) & 3-Epi-periplogenin & $\begin{array}{l}\text { A. vernalis } \\
\text { A. aleppica } \\
\text { A. aestivalis }\end{array}$ & $\begin{array}{l}\text { Mathe and Mathe, 1979a,b; Junior and } \\
\text { Wichtl, 1980; Kopp et al., } 1992\end{array}$ \\
\hline (10) & $\begin{array}{l}17 \beta-\left(2^{\prime}, 5^{\prime} \text {-dihydro- } 5^{\prime} \text {-oxo- } 3^{\prime} \text {-furyl)- } 5 \beta-14 \beta \text {-androstane- }\right. \\
3 \alpha, 5 \beta, 14 \beta \text {-triol }\end{array}$ & A. vernalis & Mathe and Mathe, 1979a,b \\
\hline (11) & Adonitoxigenin 2-O-acetylrhamnosidoxyloside & A. vernalis & Peter and Max, 1980 \\
\hline (12) & Adonitoxigenin 3-O-acetylrhamnosidoxyloside & A. vernalis & Winkler and Wichtl, 1985 \\
\hline (13) & Adonitoxigenin rhamnosidoxyloside & A. vernalis & Winkler and Wichtl, 1985 \\
\hline (14) & $\begin{array}{l}\text { Adonitoxigenin 3-O-[ } \beta \text {-D-glucopyranosyl-( } 1 \rightarrow 4)-\alpha-L- \\
\text { rhamnopyranoside }\end{array}$ & A. vernalis & Winkler and Wichtl, 1986 \\
\hline (19) & Strophanthidin-diginoside & A. aleppica & Junior and Wichtl, 1980 \\
\hline (20) & Uzarigenin-3-O-sulfate & A. aleppica & Pauli and Junior, 1993 \\
\hline (21) & Alepposide A & A. aleppica & Pauli and Junior, 1993; Pauli, 1995 \\
\hline (22) & Alepposide B & A. aleppica & Pauli and Junior, 1993; Pauli, 1995 \\
\hline (23) & Alepposide C & A. aleppica & Pauli and Junior, 1993; Pauli, 1995 \\
\hline (24) & Alepposide D & A. aleppica & Pauli and Junior, 1993; Pauli, 1995 \\
\hline (25) & Sarmentocymarin & A. aleppica & Pauli and Junior, 1993; Pauli, 1995 \\
\hline (26) & Aleppotrioloside & A. aleppica & Matthiesen et al., 1992 \\
\hline (27) & Somalin & $\begin{array}{l}\text { A. amurensis } \\
\text { A. pseudoamurensis }\end{array}$ & Ma et al., 1985; Yin et al., 2014 \\
\hline (28) & Cymarol & A. amurensis & You et al., 2003 \\
\hline (29) & Strophanthidin & $\begin{array}{l}\text { A. amurensis } \\
\text { A. aestivalis } \\
\text { A. wolgensis } \\
\text { A. chrysocyathus } \\
\text { A. sibiricus } \\
\text { A. tianschanicus } \\
\text { A. turkestanicus }\end{array}$ & $\begin{array}{l}\text { Ponomarenko et al., 1971a; Genkina } \\
\text { et al., 1972; Komissarenko et al., } \\
\text { 1973a,b,c, 1977; Zheng, 1975; Yatsyuk } \\
\text { et al., 1983; Yin et al., } 2014\end{array}$ \\
\hline (30) & Strophanthidol & A. amurensis & Ponomarenko et al., 1971a \\
\hline
\end{tabular}


TABLE 2 | Continued

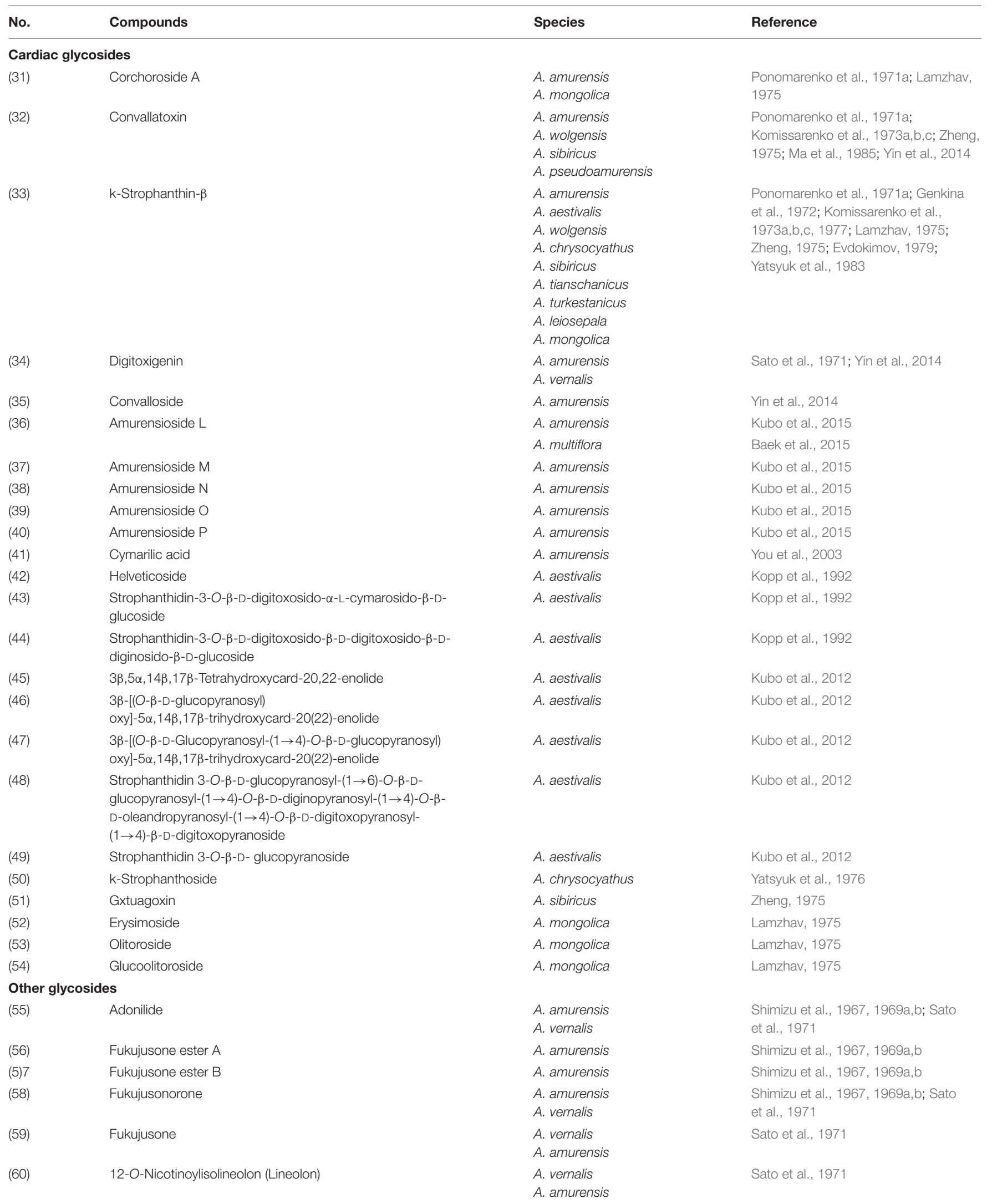


TABLE 2 | Continued

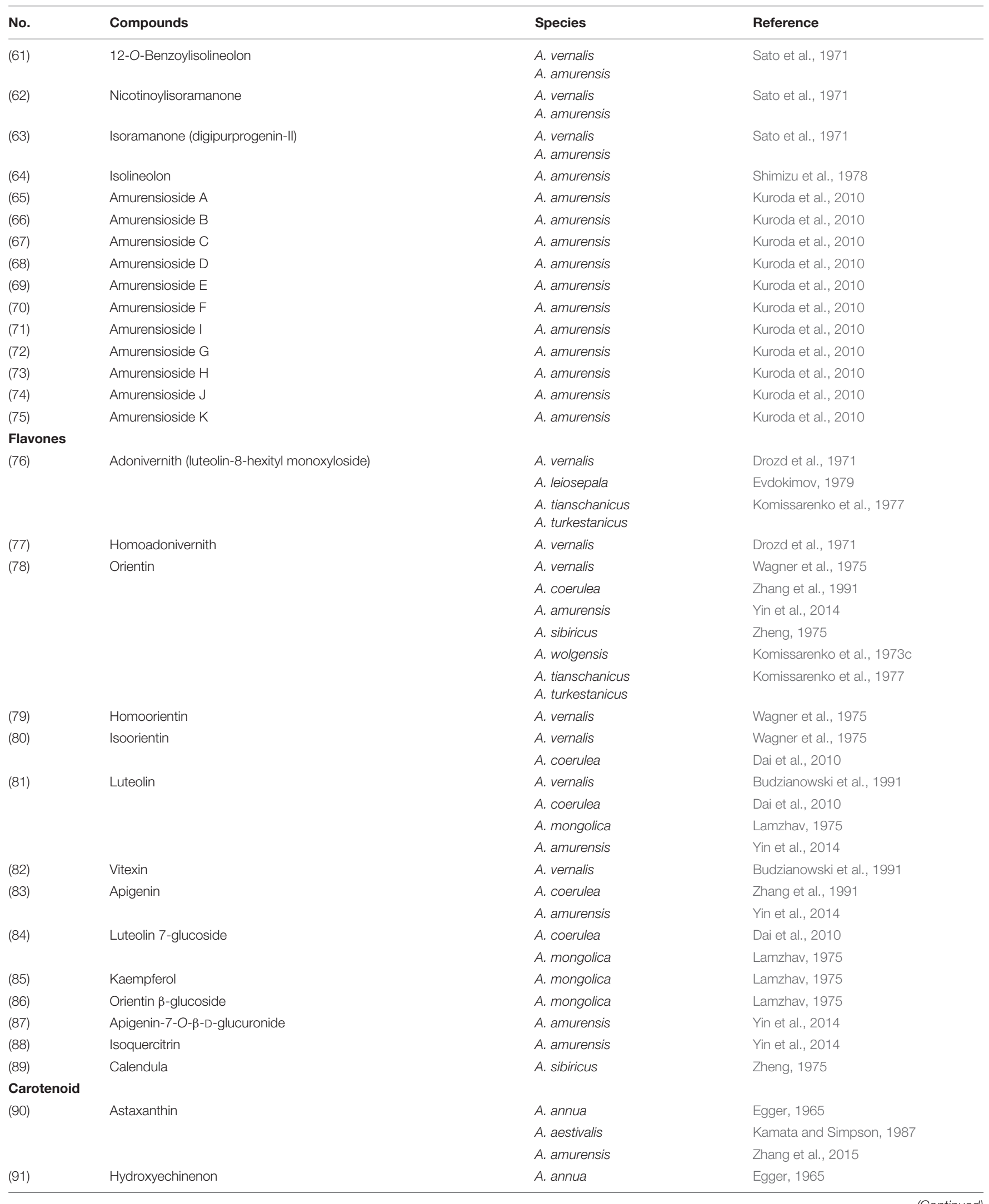


TABLE 2 | Continued

\begin{tabular}{|c|c|c|c|}
\hline No. & Compounds & Species & Reference \\
\hline (93) & Adonixanthin & A. annua & Egger, 1965 \\
\hline (95) & $3,4,4^{\prime}$-Trikcto- $\beta$-carotene & A. annua & Egger and Kleinig, 1967b \\
\hline (96) & Astaxanthin ester & A. annua & Egger and Kleinig, 1967a \\
\hline (97) & 3-Hydroxyechinenone ester & A. annua & Egger and Kleinig, 1967a \\
\hline (99) & 3-Hydroxycanthaxanthin ester & A. annua & Egger and Kleinig, 1967a \\
\hline (100) & Adonixanthin diester & A. annua & Renstrøm et al., 1981 \\
\hline (101) & 3-Hydroxy-echinenone ester & A. annua & Renstrøm et al., 1981 \\
\hline (102) & Cis-astaxanthin diester & A. annua & Renstrøm et al., 1981 \\
\hline (103) & Trans-astaxanthin diester & A. annua & Renstrøm et al., 1981 \\
\hline (104) & Adonirubin ester & A. annua & Renstrøm et al., 1981 \\
\hline (107) & Umbelliferone & A. amurensis & Ponomarenko et al., $1971 \mathrm{~b}$ \\
\hline & & A. wolgensis & Komissarenko et al., 1973c \\
\hline & & A. leiosepala & Evdokimov, 1979 \\
\hline & & A. mongolica & Lamzhav, 1983 \\
\hline \multirow[t]{4}{*}{ (108) } & Scopoletin & A. amurensis & Ponomarenko et al., 1971b \\
\hline & & A. wolgensis & Komissarenko et al., 1973c \\
\hline & & A. leiosepala & Evdokimov, 1979 \\
\hline & & A. mongolica & Lamzhav, 1983 \\
\hline \multicolumn{4}{|c|}{ Others } \\
\hline (109) & Linolenic acid & A. wolgensis & Mohadjerani et al., 2014 \\
\hline (110) & Oleic acid & A. wolgensis & Mohadjerani et al., 2014 \\
\hline (116) & $\beta$-Sitosterol & A. coerulea & Zhang et al., 1991 \\
\hline (117) & 1-Hentriacontanol, & A. coerulea & Dai et al., 2010 \\
\hline (118) & $P$-formylcinnamic acid & A. coerulea & Dai et al., 2010 \\
\hline (119) & Sugoroside & A. chrysocyathus & Genkina et al., 1972 \\
\hline (120) & Adoligose A & A. aleppica & Pauli, 1995 \\
\hline (121) & Adoligose B & A. aleppica & Pauli, 1995 \\
\hline (122) & Adoligose C & A. aleppica & Pauli, 1995 \\
\hline (123) & Adoligose D & A. aleppica & Pauli, 1995 \\
\hline (124) & Adoligose E & A. aleppica & Pauli, 1995 \\
\hline (125) & Pinoresinol & A. amurensis & Yin et al., 2014 \\
\hline (126) & Pinoresinol-8-O- $\beta$-D-glucopyranoside & A. amurensis & Yin et al., 2014 \\
\hline (127) & $\begin{array}{l}\text { 9'-Decarboxy rosmarinic acid- } 4^{\prime} \text {-O- }(1 \rightarrow 4) \text {-galactosyl } \\
\text { rhamnoside }\end{array}$ & A. amurensis & Yin et al., 2014 \\
\hline
\end{tabular}

plant (Matthiesen et al., 1992; Pauli and Junior, 1993; Pauli, 1995).

Investigation of the chemical constituents of $A$. amurensis roots has been on-going since the 1960s, with more than 20 pregnanes and cardenolides isolated and identified. In 1971, eight cardenolides were isolated by Ponomarenko et al. (1971a), including cymarin (1), somalin (27), cymarol (28), strophanthidin (29), strophanthidol (30), corchoroside A (31), convallatoxin (32) and k-strophanthin- $\beta$ (33). Subsequently, digitoxigenin (34) and convalloside (35) were identified from this plant (Shimizu et al., 1978; Yin et al., 2014). Kubo et al. (2015) isolated five new cardenolide glycosides, amurensiosides L-P 

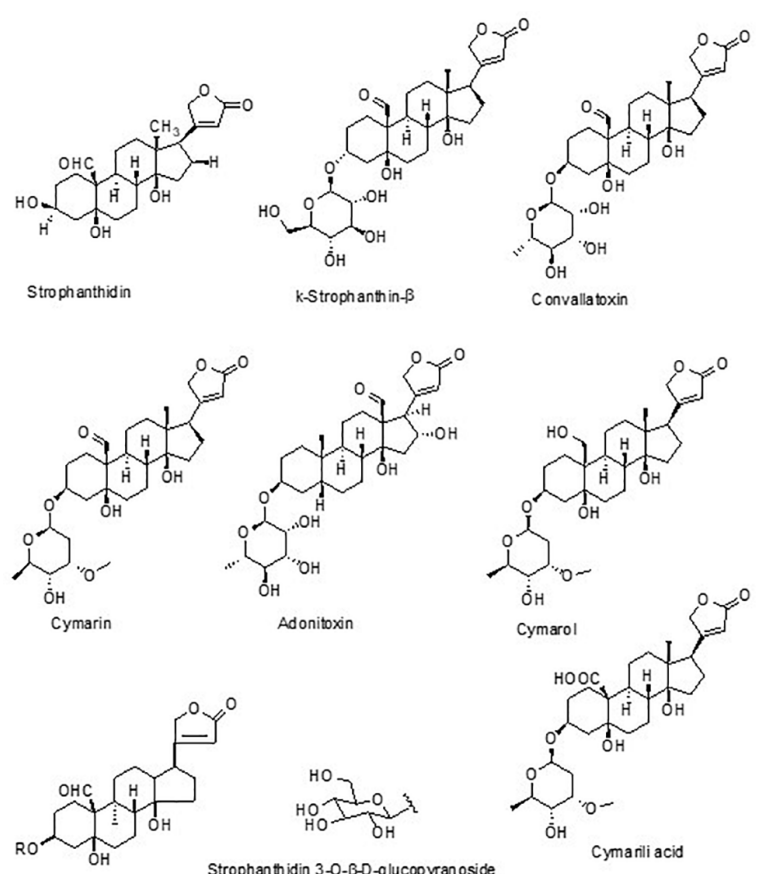

Strophanthidin 3-O-B-D-glucopyran oside

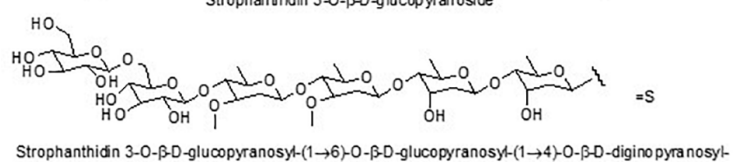

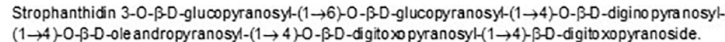

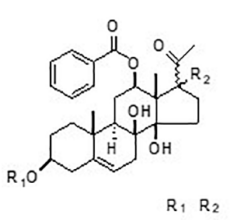

Amurensioside $A \quad S_{1} \quad \alpha-H$ Amurensioside $B \quad S, \quad B-H$
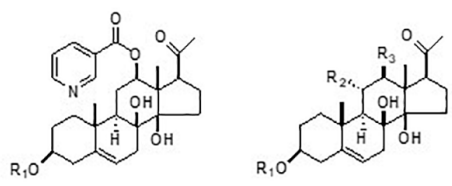

$\begin{array}{llll}R_{1} & R_{2} & R_{3}\end{array}$

Amurensioside $D \quad S_{1} \quad H \quad O H$

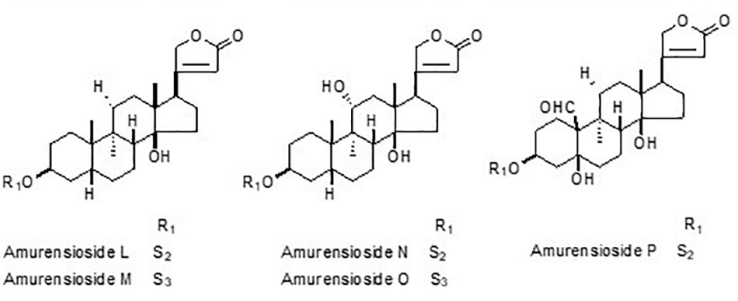

Amurensioside $M \quad S_{3} \quad$ Amurensioside $0 \quad S_{3}$

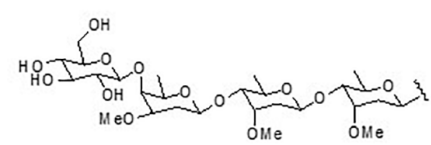

$=S_{1}$
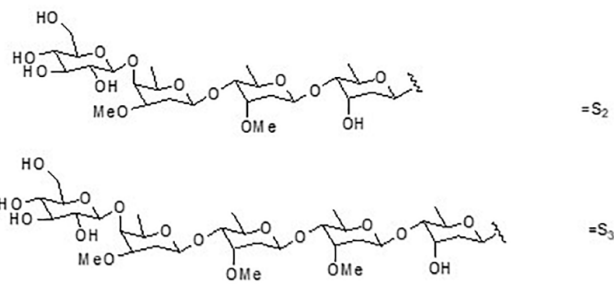

FIGURE 2 | The chemical structure of some active compounds from the genus Adonis.

(36-40). In 2003, antiangiogenic activity-guided fractionation and isolation carried out on the methanol extract of $A$. amurensis led to the identification of three compounds, namely, cymarin, cymarol, and cymarilic acid (41) (You et al., 2003). Digitoxigenin (34) was isolated from both A. vernalis and A. amurensis (Sato et al., 1971).

Adonis aestivalis is an annual plant with a crimson flower, distributed throughout southern Europe and Asia. Yatsyuk et al. (1983) first investigated the epigeal phytochemicals of $A$. aestivalis, which included strophanthidin and $\mathrm{k}$-strophanthidin- $\beta$. In 1992, four cardenolides were isolated for the first time from the aerial parts of the plants, including 3-epi-periplogenin, helveticoside (42), strophanthidin-3-O$\beta$-D-digitoxosido- $\alpha$-L-cymarosido- $\beta$-D-glucoside (43) and strophanthidin-3-O- $\beta$-D-digitoxosido- $\beta$-D-digitoxosido- $\beta$-D-dig inosido- $\beta$-D-glucoside (44); the first two compounds have been isolated from other species as well (Kopp et al., 1992). Kubo et al. (2012) has investigated the chemical compounds in the seeds of $A$. aestivalis, and a new cardenolide $\quad 3 \beta, 5 \alpha, 14 \beta, 17 \beta$-tetrahydroxycard-20,22-enolide (45) was found along with its two new glycosides $3 \beta-[(O-\beta-D-$ glucopyranosyl)oxy]-5 $\alpha, 14 \beta, 17 \beta$-trihydroxycard-20(22)-enolide (46), and $3 \beta-[(O-\beta$-D-glucopyranosyl- $(1 \rightarrow 4)-O-\beta-\mathrm{D}-$ glucopyranosyl)oxy]-5 $\alpha, 14 \beta, 17 \beta$-trihydroxycard-20(22)-enolide (47). A new strophanthidin hexaglycoside, strophanthidin 3-O-
$\beta$-D-glucopyranosyl- $(1 \rightarrow 6)-O-\beta$-D-glucopyranosyl- $(1 \rightarrow 4)-O-\beta$ D-diginopyranosyl-( $1 \rightarrow 4)-O-\beta$-D-oleandropyranosyl- $(1 \rightarrow 4)-O$ $\beta$-D-digitoxopyranosyl- $(1 \rightarrow 4)-\beta$-D-digitoxopyranoside $(48)$, as well as strophanthidin 3-O- $\beta$-D-glucopyranoside (49) were also isolated (Kubo et al., 2012).

A. multiflora is native to Korea, Japan, and Manchuria. In 2015, amurensioside L (36) was isolated from the whole plant (Baek et al., 2015). A. leiosepala yielded cymarin and k-strophanthin- $\beta$ (Evdokimov, 1979). These two compounds, along with strophanthidin and convallatoxin, were isolated from A. wolgensis (Komissarenko et al., 1973a,b,c). Strophanthidin, cymarin, k-strophanthin- $\beta$, k-strophanthoside (50) and adonitoxin were identified in extracts of $A$. chrysocyathus (Aitova et al., 1971; Genkina et al., 1972; Yatsyuk et al., 1976). Then, the related plant $A$. sibiricus afforded strophanthidin, k-strophanthidin- $\beta$, convallatoxin and gxtuagoxin (51) (Zheng, 1975).

Lamzhav (1975) isolated cymarin, adonitoxin, corchoroside A, k-strophanthin- $\beta$, k-strophanthoside, erysimoside (52), olitoroside (53) and glucoolitoroside (54) from A. mongolica (Thieme and Lamzhav, 1976). Komissarenko et al. (1977) isolated the cardenolides strophanthidin, cymarin and k-strophanthin- $\beta$ from $A$. tianschanicus and A. turkestanicus. Finally, somalin, cymarin, and Convallatoxin were identified in A. pseudoamurensis (Ma et al., 1985). 


\section{Other Glycosides}

Shimizu et al. (1967, 1969a,b) identified an aglycone-adonilide (55); three novel compounds, namely, fukujusone, ester A (56) and ester B (57); and the 18-norpregnane derivative fukujusonorone (58) in A. amurensis. Adonilide (55), fukujusone (59), 12-O-nicotinoylisolineolon (lineolon, 60), 12-O-benzoylisolineolonb (61) and fukujusonorone (58), together with nicotinoylisoramanone (62), digitoxigenin, and isoramanone (digipurprogenin-II, 63) were isolated from A. vernalis and A. amurensis (Sato et al., 1971). Isolineolon (64) was also isolated from this plant (Shimizu et al., 1978).

In 2010, five new pregnane tetraglycosides known as amurensiosides A-E (65-69); two new pregnane hexaglycosides, amurensiosides F (70) and I (71); two new 18-norpregnane hexaglycosides, amurensiosides $\mathrm{G}$ (72) and $\mathrm{H}$ (73); and two new pregnane octaglycosides, amurensiosides J (74) and K (75), were isolated from the $\mathrm{MeOH}$ extracts of the roots of $A$. amurensis (Kuroda et al., 2010). A new pregnane hexaglycoside was isolated from the whole plant (Baek et al., 2015).

\section{Flavones}

Along with the isolated cardiac compounds, many flavones were also identified. Adonivernith (luteolin-8-hexityl monoxyloside) (76), homoadonivernith (77), orientin (78), homoorientin (79), isoorientin (80), luteolin (81) and vitexin (82) were isolated from A. vernalis (Chernobai et al., 1968; Drozd et al., 1971; Wagner et al., 1975; Budzianowski et al., 1991), and adonivernith also was found in A. leiosepala (Evdokimov, 1979).

Orientin, apigenin (83), luteolin, isoorientin and luteolin 7-glucoside (84) were isolated from A. coerulea Maxim. (Zhang et al., 1991; Dai et al., 2010). Lamzhav (1975, 1983) isolated luteolin, kaempferol (85), luteolin 7-glucoside, and an orientin $\beta$-glucoside (86) from $A$. mongolica, and luteolin, apigenin, apigenin-7-O- $\beta$-D-glucuronide (87), orientin and isoquercitrin (88) were found in $A$. amurensis (Yin et al., 2014). Orientin was identified from A. sibiricus (Zheng, 1975). Komissarenko et al. (1973c) has identified the flavonoid orientin from $A$. wolgensis, while the orientin and adonivernitol were isolated from the herbs A. tianschanicus and A. turkestanicus (Komissarenko et al., 1973b, 1977).

\section{Carotenoids}

In 1965, astaxanthin (90), along with three minor red compounds known as hydroxyechinenon (91), adonirubin $\left(4,4^{\prime}\right.$-diketo-3-hydroxy- $\beta$-carotene) $(92)$ and adonixanthin $\left(3,3^{\prime}\right.$ hydroxy-4-keto- $\beta$-carotene) (93) were identified from the red flowers of $A$. annua (Egger, 1965). Astaxanthin also was found in $A$. amurensis (Zhang et al., 2015). 3,4-Diketo- and $3,4,4^{\prime}$-triketo- $\beta$-carotene $(94,95)$ were also isolated (Egger and Kleinig, 1967b). The fatty acid components of the ketocarotenoid esters, including esters of astaxanthin (96), 3-hydroxyechinenone (97), 3,3'-dihydroxyechinenone (98) and 3-hydroxycanthaxanthin (99) were also investigated (Egger and Kleinig, 1967a). In 1981, the carotenoid composition of the red flower petals of $A$. annua was elucidated and included adonixanthin diester (100), 3-hydroxy-echinenone ester (101), cis-astaxanthin diester (102), trans-astaxanthin diester (103), adonirubin ester (104), cis-astaxanthin monoester (105) and trans-astaxanthin monoester (106) (Renstrøm et al., 1981). In1987, from $A$. aestivalis astaxanthin diester also was isolated (Kamata and Simpson, 1987).

\section{Coumarins}

The two coumarins umbelliferone (107) and scopoletin (108) were isolated from the roots of $A$. amurensis, $A$. wolgensis, A. leiosepala, and A. mongolica (Ponomarenko et al., 1971b; Komissarenko et al., 1973c; Evdokimov, 1979; Lamzhav, 1983).

\section{Others}

Mohadjerani et al. (2014) studied the fatty acids of A. wolgensis, and the results showed that linolenic acid $(45.83 \%, 109)$ and oleic acid $(47.54 \%, 110)$ were the most abundant fatty acids found in the leaves and stems, respectively. Zhang et al. (1991) found that stigmast-4-ene-3,6-dione (111), stigmast-4-ene-3one $6 \beta$-hydroxy (112), $\beta$-D-glucopyranoside (113), palmitic acid (114), adonitol (115), and $\beta$-sitosterol (116) existed in $A$. coerulea. 1 -Hentriacontanol (117) and $p$-formylcinnamic acid (118) were also found in this plant (Dai et al., 2010).

A new tetraoside, sugoroside (119) was identified in the extracts of A. chrysocyathus (Genkina et al., 1972), and the pentahydric alcohol adonitol was found in A. mongolica and A. leiosepala (Evdokimov, 1979). Five novel tri-, tetra-, and pentasaccharides named adoligoses A-E (120-124), consisting of rare dideoxy sugars and their 3-OMe ethers, have been isolated from A. aleppica (Pauli, 1995).

Three lignans, namely, pinoresinol (125), pinoresinol-8-O$\beta$-D-glucopyranoside (126) and 9'-decarboxy rosmarinic acid$4^{\prime}$-O-(1 $\left.\rightarrow 4\right)$-galactosyl rhamnoside $(127)$, were isolated from A. amurensis (Yin et al., 2014).

\section{ANALYSIS OF ACTIVE CONSTITUENTS AND QUALITY CONTROL}

Due to the marked cardiac-enhancing effects, Adonis spp. have long been used in European and Chinese folk medicine, and some species, such as A. amurensis, have been historically applied in the clinic to treat heart diseases. To examine the active compound content in different parts of the plants and in different species, high-performance liquid chromatography (HPLC) and other chromatographic methods were utilized. Wang et al. (1991) reported that the highest content of total cardenolide glycosides was found in the roots of $A$. amurensis during the germination period with the lowest content levels isolated during the mature fruit phase. Chromatography of cardiac glycosides in $A$. amurensis used $\mathrm{CH}_{3} \mathrm{OH}: \mathrm{H}_{2} \mathrm{O}(65: 35)$ as the mobile phase with an ODS column $(150 \mathrm{~mm} \times 6.0 \mathrm{~mm})$ at a flow rate of $0.80 \mathrm{~mL} / \mathrm{min}$ monitored at $218 \mathrm{~nm}$. The contents of convallatoxin, strophanthidin, cymarin, and aglycones A and B found in cardenolide-enriched extract were 6.58, 2.09, 2.54, 4.49, and $2.11 \%$, respectively, in a chloroform-ethanol (1:1) fraction of an ethanolic extract ( $\mathrm{Gu}$ et al., 1990). Liu and Cui (2007) studied the content of convallatoxin of A. amurensis obtained from various habitats throughout China. The results quantified 
the contents of the aerial parts and roots harvested from Liaoning province $(0.0022$ and $0.1400 \%)$, Jilin province $(0.0019$ and $0.1300 \%)$ and Heilongjiang province $(0.0014$ and $0.0790 \%)$. The amounts of somalin, k-strophanthoside and k-strophanthin- $\beta$ in A. pseudoamurensis were determined to be $0.024,0.13$, and $0.071 \%$, respectively (Gu et al., 1989).

\section{PHARMACOLOGY}

\section{Cardiovascular Effect}

In 1918, the cardiovascular effect and the toxicity was firstly assayed using the 1-h frog method. Results showed that at the concentration of $0.0045 \mathrm{~mL} / \mathrm{g}$ frog of ten percent of $95 \%$ ethanol extract of $A$. vernalis could result in a permanent systole (M.S.D.) of the frog's ventricle at the end of $1 \mathrm{~h}$ (Heyl et al., 1918). In the early 1930s, Munch and Krantz (1934) reported that A. vernalis and its preparations exhibited the same level of potency in the heart as digitalis and the corresponding digitalis preparations using the 1-h frog method. Studies by Benson and Edwards (1941) showed that the pigeon emetic method is suitable for the assay of A. vernalis, and the percent potency of tincture of Adonis assays was $100 \%$ by the frog method, $91.6 \%$ by the cat method, and $85.37 \%$ by the pigeon emetic method. Subsequently, Lehmann (1984) studied the cardiac inotropic and constrictor of SCOA (contained extracts from Scilla, Convallaria, Oleander, and Adonis) in cats in vivo. At the dose of $21.5-100 \mathrm{GPU} / \mathrm{kg}$ (GPU, guinea-pig unites), SCOA after intravenous injection had a positive inotropic and constrictor effect on veins and arteries. According to the studies of Turova and Sapozhnikova (1989), the raw material of Adonis is as effective as Digitalis in the heart failure accompanied by cardiac conduction disturbance; but the effects are not cumulative and could not result in the phenomenon of a cardiac arrest caused by Digitalis. Meanwhile, substance $\mathrm{N}(7)$ from the leaves of $A$. vernalis exhibited a highly potent digitalis-like mode-of-action, with a geometrical mean $\mathrm{LD}$ of $0.1141 \pm 0.0040 \mathrm{mg} / \mathrm{kg}$ in cats (Büchner et al., 1965). Moreover, the potent antihyperlipidemic activity of the alcoholic extract of A. vernalis also was found. At the concentration of $5 \mathrm{mg} / \mathrm{kg}$, it could significant decrease the serum cholesterol and triglycerides compared with control, triton-induced hyperlipidemic control and positive control (simvastatin, $20 \mathrm{mg} / \mathrm{kg})(p<0.05)$. And it also slightly increased HDL, clear decrease in LDL and total protein (Lateef et al., 2012).

Kuo et al. (1962) first studied the cardiac activity of A. amurensis. The results showed that it has a similar effect to A. vernalis, and it could enhance contractions of an isolated frog heart and increase the contractions and diastole of an isolated rabbit heart. After assaying for 20-30 min, the contractions and diastole became weak, and the heartbeat stopped at the systolic stage. Moreover, it enhanced the contractions of a dog heart and increased the blood pressure while decreasing the venous pressure of a heart in failure. Further electrocardiogram tests showed that it extended the $\mathrm{P}-\mathrm{Q}$ interval and shortened the R-T interval, indicating that $A$. amurensis could influence metabolism of heart muscle, enhance heart muscle contractions, delay atrioventricular conduction and improve the overall function of the heart.
Additionally, the effect of the cardenolide-enriched extract on treatment of premature ventricular contraction was also reported (Dong, 1981). To investigate the mechanism of action for treating arrhythmia, the electrophysiology of rat cardiac muscle cells was studied. The results showed that after injecting $0.5 \mathrm{mg} / \mathrm{kg}$ cardenolide-enriched extract $(0.5 \mathrm{mg} / \mathrm{kg})$ in anesthetized rats $(10 \%$ urethane, $0.5 \mathrm{~g} / \mathrm{kg}$ ), the repolarization action potential time limit (APD) lengthened, particularly at 90\% APD, and the conduction velocity of action potential was slowed ( $\mathrm{Gu}$ et al., 1981). When it was intravenously injected $(0.1 \mathrm{mg} / \mathrm{kg})$ in anesthetized dogs, the $\mathrm{dp} / \mathrm{dt}$ max value increased significantly from $5 \mathrm{~min}$ to $30 \mathrm{~min}(p<0.01)$, and this value was maintained after $1 \mathrm{~h}$. In contrast to the value of $\mathrm{dp} / \mathrm{dt} \max$, the heart rate of dogs significantly decreased $(p<0.001)$ immediately after injecting the extract, and while the time lengthened, the effect gradually weakened. Further studies showed the above trends did not change with administration of a $\beta$-receptor blocker, and this result indicated that $\beta$-receptor stimulation and release of endogenous catecholamine are not factors in the positive inotropic action of this extract. Additionally, the effect of myocardial potassium loss promoted by the total glycosides was presented in this research (Shi et al., 1979). The extract also enhanced the antiarrhythmic activity of disopyramide (Shen et al., 1983). To thoroughly exploit the resources of A. amurensis, the cardiotonic activities of the ethanol extract of leaves, stems, and roots were investigated. Results showed that all extracts exerted cardiotonic effects on the movement of a rabbit atrial muscle (Qin, 2000).

Deng et al. (1963) first proved that the total glycosides of A. brevistyla, found in the Yunan province of China, had cardiotonic effects. The results showed that injecting the total glycoside preparation could stop the muscle contraction of Rana pleuraden in the contraction phase when anesthetized with urethane and could enhance heart muscle contractions of rabbits after injections of $10 \%$ pentobarbital sodium. The $\mathrm{LD}_{50}$ value in pigeons was $7.08 \pm 0.15 \mathrm{mg} / \mathrm{kg}$.

The cardiotonic effects of cardenolide-enriched extract of A. pseudoamurensis on the heart failure of rabbits were studied and found to significantly improve the heart function in heart failure, while enhancing the $\mathrm{dp} / \mathrm{dt} \max ,-\mathrm{dp} / \mathrm{dt} \max , \mathrm{Co}$, and Lvsp of the heart with increased rates of $210 \pm 33 \%$, $70 \pm 17 \%, 191 \pm 51 \%$, and $31 \pm 30 \%$, respectively (Chi et al., 1985). Oral administration of methyluracil lowered the sensitivity to strophanthin both in rabbits with myocardial infarction and in intact mice; intravenous administration of methyluracil increased the coronary circulation rate (Lazareva, 1975).

Maham and Sarrafzadeh-Rezaei (2014) reported the cardiovascular effects of $A$. aestivalis in anesthetized sheep. The results showed that after intravenously administering three successive equal doses $(75 \mathrm{mg} / \mathrm{kg}$ ) of the hydroalcoholic extract to anesthetized sheep, the extract induced significant bradycardia, hypotension, and various ECG abnormalities. Ventricular arrhythmias, bradyarrhythmias, atrioventricular blockage, premature ventricular beats, ventricular tachycardia, and ventricular fibrillation were observed. The acute intraperitoneal toxicity $\left(\mathrm{LD}_{50}\right)$ of the extract in mice was $2150 \mathrm{mg} / \mathrm{kg}$. The bradycardia and ECG alterations induced by the extract justified 
the traditional use of this plant in treating cardiovascular insufficiency (Table 3).

\section{Antiangiogenic Activity}

Adonis amurensis has been used in folk medicine for the treatment of several diseases such as cardiac insufficiency and edema (Bae, 2000), and the methanol extract was found to exhibit strong inhibitory activity on human umbilical vein endothelial cells (HUVEC) tube formation (Bae et al., 2000). The antiangiogenic activities of three compounds, namely, cymarin, cymarol, and cymarilic acid were studied. Among three compounds, cymarilic acid exhibited strong inhibition of human umbilical venous endothelial (HUVE) cell-induced tube formation, with inhibition rates of $80-60 \%$ at a concentration of $1 \mu \mathrm{g} / \mathrm{mL}$. Cymarin and cymarol exhibited the same inhibitory activity against HUVE cells as the former compound (You et al., 2003) (Table 3).

\section{Cytotoxicity}

In 2010, the cytotoxicity of four active compounds was found. Amurensioside A, amurensioside B, amurensioside $\mathrm{D}$, and amurensioside $\mathrm{E}$ were moderately cytotoxic to HSC-2 cells with $\mathrm{IC}_{50}$ values of $66,26,47$, and $58 \mu \mathrm{g} / \mathrm{mL}$, respectively; the activity of the positive control melphalan

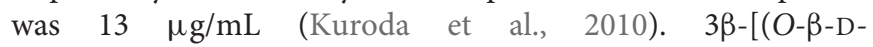
glucopyranosyl)oxy]-5 $\alpha, 14 \beta, 17 \beta$-trihydroxycard-20(22)-enolide (46), strophanthidin $3-O-\beta-D-$ glucopyranosyl- $(1 \rightarrow 6)-O-\beta$-Dglucopyranosyl- $(1 \rightarrow 4)$ - $O$ - $\beta$-D-diginopyranosyl- $(1 \rightarrow 4)-O-\beta$-Doleandropyranosyl- $(1 \rightarrow 4)$ - $O$ - $\beta$-D-digitoxopyranosyl- $(1 \rightarrow 4)-\beta$ D-digitoxopyranoside (48), as well as strophanthidin 3-O- $\beta$-Dglucopyranoside (49) displayed selective cytotoxicity toward malignant tumor cell lines including HSC-2, HSC-3, HSC-4, and HL-60 cells with a $\mathrm{CC}_{50}$ range of $0.012-2.8 \mu \mathrm{M}$. Studies also indicated that they may trigger caspase-3-independent apoptotic cell death in HL-60 and HSC-2 cells. The $\mathrm{CC}_{50}$ values of the positive control melphalan were 8.7, 25,32, and $1.4 \mu \mathrm{M}$ in HSC-2, HSC-3, HSC-4, and HL-60 cells, respectively (Kubo et al., 2012). Five new cardenolide glycosides, amurensiosides L-P showed cytotoxic activities against HL-60 promyelocytic and HSC-2 cells (Kubo et al., 2015). Cymarin and cymarol showed potent cytotoxicity against A549 cells $(0.031$ and $0.021 \mu \mathrm{g} / \mathrm{mL})$ while being inactive toward L1210 cells $(5 \mu \mathrm{g} / \mathrm{mL}$ ) (You et al., 2003). Cymarilic acid showed no significant cytotoxicity against the human solid tumor cell line $\mathrm{A} 549\left(\mathrm{ED}_{50}>5 \mu \mathrm{g} / \mathrm{mL}\right)$, and was inactive toward murine leukemic cells L1210 $\left(\mathrm{ED}_{50}>5 \mu \mathrm{g} / \mathrm{mL}\right)$ (Table 3).

\section{Effect on the Central Nervous System}

In 1980, Gu et al. (1980) studied the effect of the cardenolideenriched extract of $A$. amurensis on the central nervous system of rabbits. After injecting the extract $(0.3$ and $0.5 \mathrm{mg} / \mathrm{kg}$, i.v.) in rabbits, the electroencephalogram (EEG) presented a high amplitude slow wave, and the response of rabbits to sound became weak. The sedative effect of the total glycosides may be related to its inhibitory effect on the cerebral cortex and the reticular structure. Additionally, the spontaneous electro discharge in the neck was decreased, while the 5-HT content in the brain increased significantly at a concentration of $0.5 \mathrm{mg} / \mathrm{kg}$. This result also showed that the glycosides induced peripheral muscle relaxation. Moreover, injecting the extract (5-15 $\mu \mathrm{g})$ in the brain would stimulate the rabbits. Stimulation decreased when scopolamine $(2 \mathrm{mg}$ ) was administered to rabbits (Table 3 ).

\section{Free Radical Scavenging Capacity}

In 2014, the free radical scavenging capacity of A. wolgensis in DPPH radical scavenging assay was studied. Total phenolic content (TPC) of the hydromethanolic extract was 9.20 gallic acid equivalents/g dry matter. Studies showed that the free radical scavenging capacity of the hydro-methanolic extract had an $\mathrm{IC}_{50}$ value of $27.45 \mu \mathrm{g} / \mathrm{mL}$, while the positive control ascorbic acid was $22.23 \mu \mathrm{g} / \mathrm{mL}$. Additionally, the reducing potential of this extract (measured at $0.05-0.6 \mathrm{mg} / \mathrm{mL}$ ) showed a general increase in activity with increasing concentration (Mohadjerani et al., 2014) (Table 3).

\section{Antibacterial, Anti-inflammatory, and Antiviral Activities}

The hydro-methanolic extract of $A$. wolgensis was particularly effective against Gram-negative Salmonella enteritidis $(48 \pm 1.56 \mu \mathrm{g} / \mathrm{mL})$ and Escherichia coli $(50 \pm 1.94 \mu \mathrm{g} / \mathrm{mL})$ and against Gram-positive Staphylococcus aureus $(50 \pm 1.83 \mu \mathrm{g} / \mathrm{mL})$, but no activity was observed against Gram-positive Bacillus subtilis (Mohadjerani et al., 2014). Das et al. (2007) reported a significant inhibitory effect by the $50 \%$ methanol extract of A. vernalis on tumor necrosis factor- $\alpha$ (TNF- $\alpha$ ) production in whole blood cell culture. The $10 \%$ aqueous extract of $A$. vernalis aerial part also presented the antiviral activity with inhibition zone over $30 \mathrm{~mm}$ for Herpes virus Hominis HVP 75 (type2), influenza virus A2 (Manheim 57), Vaccini virus and poliovirus type1 (May and Willuhn, 1978) (Table 3).

\section{Diuretic Effect}

Wang et al. (1981) found that the cardenolide-enriched extract of $A$. amurensis had a diuretic effect on dogs. After injecting the drug $(0.2 \mathrm{mg} / \mathrm{kg})$ into dogs, the average amount of urine measured increased to $178.03 \mathrm{~mL}$ versus $71.58 \mathrm{~mL}$ measured in the control group. $\mathrm{Na}^{+}, \mathrm{K}^{+}$, and $\mathrm{Cl}^{+}$outputs increased by 2.9-, $1.4-$, and 1.9-fold compared to the control group, respectively. These results indicated that the total glycoside preparation has a significant diuretic effect by inhibiting the renal tubular reabsorption of $\mathrm{Na}^{+}, \mathrm{K}^{+}$, and $\mathrm{Cl}^{+}$(Table 3).

\section{Acaricidal Activity}

Adonis coerulea is a perennial plant with a height of $2-12 \mathrm{~cm}$, distributed throughout northeastern areas of Tibet and in Sichuan, Qinghai and Gansu Provinces in China at altitudes of 2300-5000 m (Chinese Materia Editorial Committee, and State Chinese Medicine Administration Bureau, 2002). In the field investigation of Sichuan and Gansu Provinces in China, A. coerulea, as a traditional Tibetan medicine to treat animal acariasis, was found (Shang et al., 2012). Further studies showed that the extract presented marked acaricidal activity against Psoroptes cuniculi with a median lethal time $\left(\mathrm{LT}_{50}\right)$ of $3.137 \mathrm{~h}$ at a 


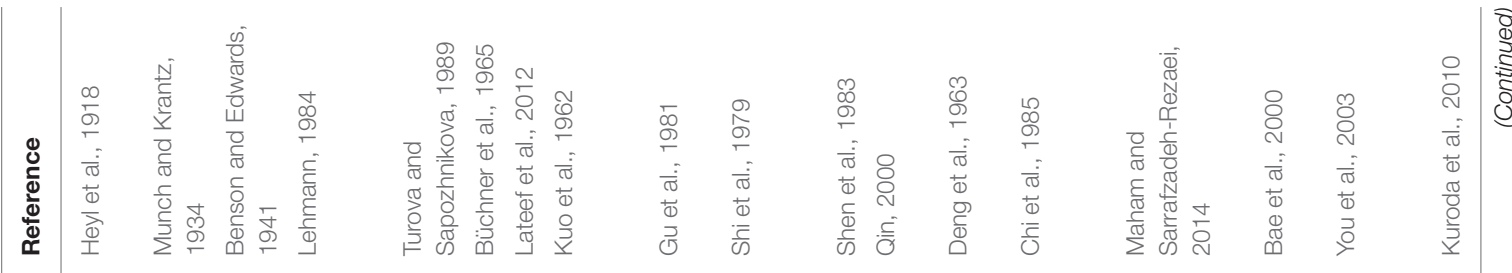

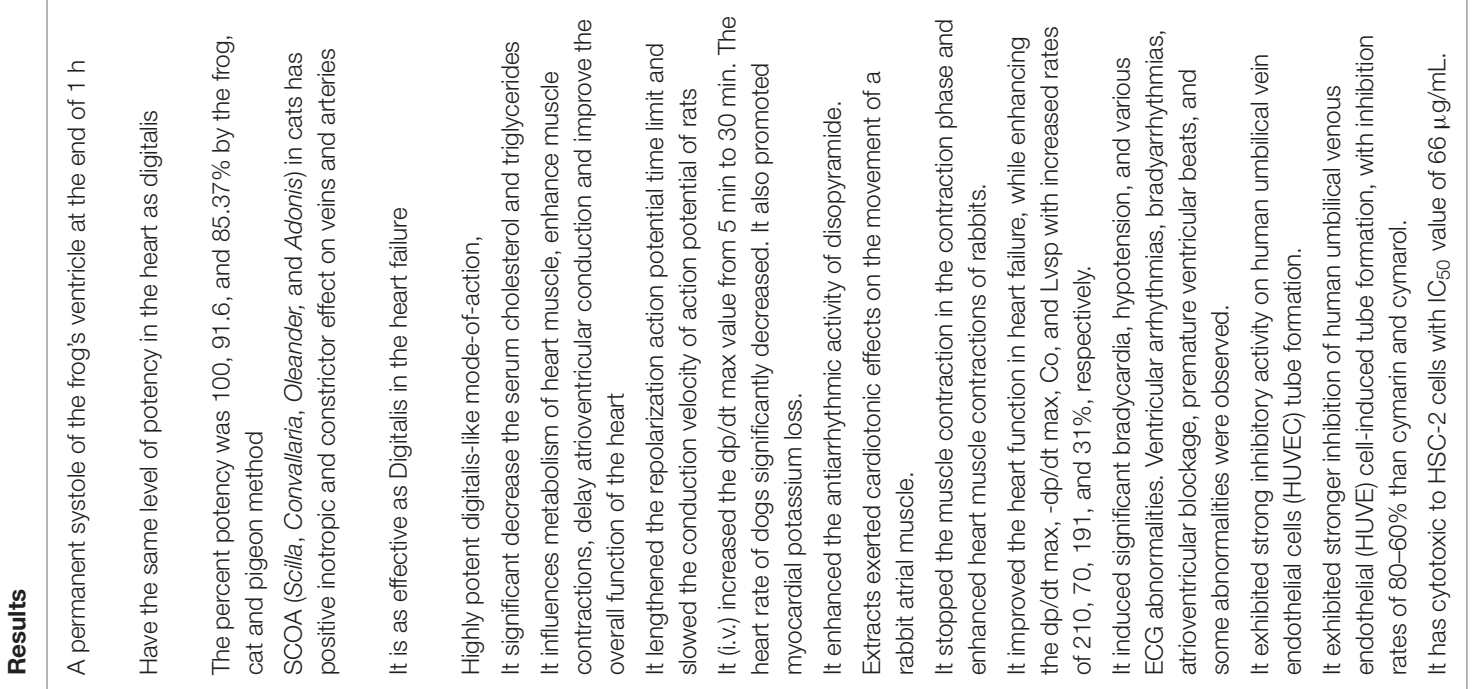

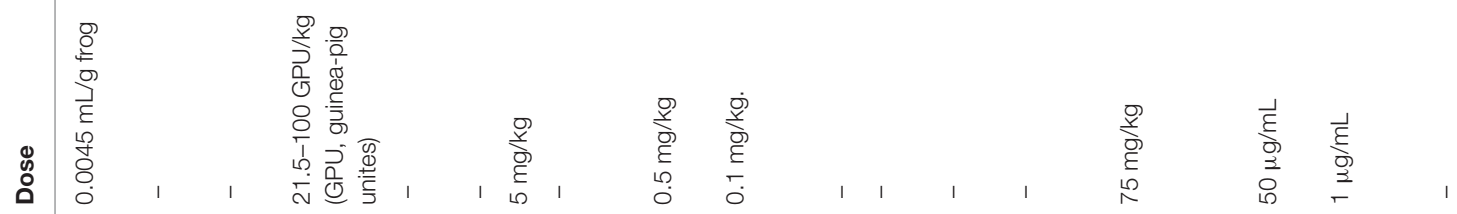<smiles>C1CCCC1</smiles>

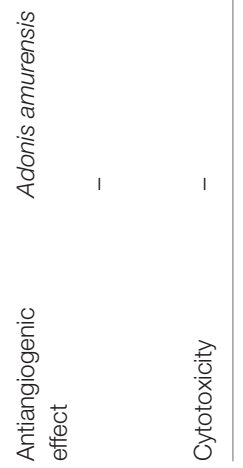




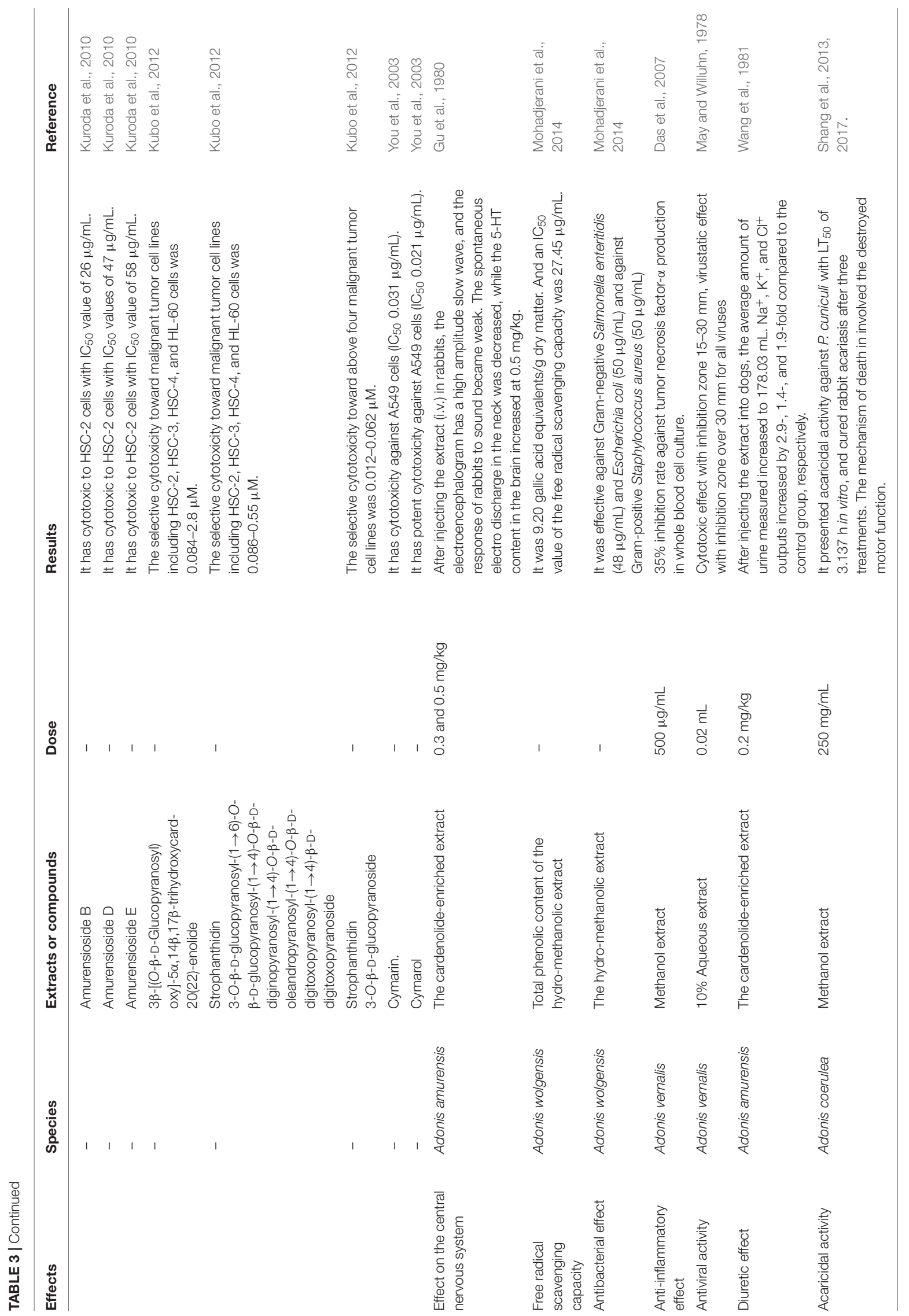


concentration of $250 \mathrm{mg} / \mathrm{mL}$ in vitro, and it cured rabbit acariasis after three treatments (Shang et al., 2013). The mechanism of death in $P$. cuniculi involved the inhibition of the dynamic equilibrium between the production and clearing of superoxide anions, which destroyed motor function (Shang et al., 2017) (Table 3).

\section{TOXICITY}

Animals consuming plants containing cardiac glycosides typically develop fatal digestive and cardiac disturbances (Galey et al., 1996), and many acute animal poisonings have been attributed to the Adonis spp. cardiac glycosides since 1912. These species include but are not limited to, A. aestivalis, A. annua, A. amurensis, A. autumnalis, and A. microcarpa (Maiden, 1912). The first experimental feeding trial was performed in 1929, and the results demonstrated that A. annua was lethal to sheep when fed $1.0 \mathrm{lb}$ of fresh plant, the seed-bearing mature stage of the plant and extracts of the partially dried plant. However, feeding cattle 2 to $6 \mathrm{lb}$ daily for 36 days failed to elicit clinical signs and death (Hurst, 1942). In 1932, toxicosis in horses was reported based on natural exposure to Adonis sp. (Degen, 1932; Kummer, 1952).

Woods et al. (2004) first reported Adonis toxicosis in North America. After eating grass hay containing A. aestivalis, three horses died. The signs of colic first appeared $24-48 \mathrm{~h}$ after initial exposure to the hay, and gastrointestinal stasis and myocardial degeneration of the horses were noted in subsequent clinical examinations. In 2007, the toxicity of $A$. aestivalis in calves was studied. Four Holstein and preruminating Jersey calves were administered $1 \%$ bodyweight of $A$. aestivalis (containing 11-98 mg/g of strophanthidin) via a stomach tube and monitored for clinical signs for 2 weeks and 1 week, respectively. The Holstein calves were then fed $0.2-1 \%$ bodyweight daily for 4-5 weeks. They had transient, mild cardiac abnormalities during the feeding trial, and mild transient gastrointestinal and cardiac signs were also noted in the preruminating calves. The above results showed that cattle are less susceptible than horses to cardiotoxic effects and sudden death after ingestion of relatively small quantities of $A$. aestivalis (Woods et al., 2007). Finally, the toxicity of $A$. aestivalis in sheep (ewes) was investigated in 2010. Results showed that after administrating 1\% bodyweight to ewes for 24 and $48 \mathrm{~h}$, the ewes all exhibited transient sinus arrhythmias, and two of the three ewes exhibited transient reduced fractional shortening. Moreover, after administering $0.2 \%$ bodyweight daily for 2 weeks, two ewes had reduced fractional shortening after the low-dose treatment regimen. No gross or microscopic lesions were seen when the ewes were examined postmortem at the end of the study (Woods et al., 2011).

In 1962, the toxicity of A. amurensis was first studied. After perfusing the cardenolide-enriched extract intravenously, the minimum lethal doses against cats and pigeons were 46.2 and $78.6 \mathrm{mg} / \mathrm{kg}$, respectively (Kuo et al., 1962). In 1973, the toxicity to cats of the total glycoside preparation of $A$. amurensis was studied by observing the electrocardiogram, with results indicating that the minimum lethal dose in cats was $0.75 \mathrm{mg} / \mathrm{kg}$ (i.v.), while the minimum lethal doses of cedilanid and k-strophanthin were 0.77 and $0.49 \mathrm{mg} / \mathrm{kg}$, respectively. The accumulative rates in body at 24 and $48 \mathrm{~h}$ were 74.2 and $23.8 \%$, respectively, and at $74 \mathrm{~h}$, the accumulative rate was less than $5 \%$. The above results indicated the accumulative toxicity of the extract was lower than that of digitoxin and convallatoxin, higher than that of k-strophanthin (Shuguang Medical Team of Anshan City et al., 1973). The minimum lethal dose in pigeons was $1.469 \pm 0.201 \mathrm{mg} / \mathrm{kg}$ (i.v.) (Shi et al., 1979). Acute toxicosis in mice and cats was also observed after intravenous administration of Adonis-like glycosides and the strophanthidin aglycone in the laboratory (Chen et al., 1951; Greeff and Kasperat, 1961).

Davies and Whyte (1989) found that feeding the seed of A. microcarpa $(5.6 \mathrm{~g} / \mathrm{kg})$ induced total feed refusal within 3 days in growing and mature pigs, causing vomiting, rapid and shallow breathing, and even one pig died. These effects were probably caused by the cardiac glycosides and subsided within 2 weeks of removal of the seed. The toxicities of active compounds also were studied. The $\mathrm{LD}_{50}$ of cymarin after intravenous injection in rats and cats were 24.8 and $95.4 \mathrm{mg} / \mathrm{g}$, respectively (Chen et al., 1942; Vogel and Kluge, 1961); and the $\mathrm{LD}_{50}$ for adonitoxin was $191.3 \mu \mathrm{g} / \mathrm{kg}$ (Chen and Anderson, 1947). Meanwhile, the average minimum dose producing a permanent systole (M.S.D.) values for above two compounds were 0.621 and $0.88 \mathrm{~g} / \mathrm{g}$ frog, respectively (Chen and Anderson, 1947). After continuous intravenous infusion in dogs, the minimal lethal doses of adonidoside and adonivernoside at $30 \mathrm{~min}$ were found to be 0.7 and $1.75 \mathrm{mg} / \mathrm{kg}$, respectively, and when they were used together, the $\mathrm{LD}_{50}$ was $1.14 \mathrm{mg} / \mathrm{kg}$ (Lenel-Pekelis, 1949). Kovaříková and Chen (1965) studied the activities of 16-hydroxystrophanthidin, 16-formyloxy-strophanthidin, acetyladonitoxin, and tetracetyladonitoxin, and results showed that the $\mathrm{LD}_{50}$ in cats were $1.121,0.1518,0.3881$, and $4.397 \mathrm{mg} / \mathrm{kg}$, respectively.

In China, cases of $A$. amurensis poisoning in humans who misused or overdosed the plant have been noted. In most cases, the patient heart rate was seriously abnormal (Wang and Feng, 1982; Sun, 1988; Zhang, 1999).

\section{CONCLUSION AND REMARKS}

Because of the marked effects as a cardiotonic agent in treating heart diseases, some species of the genus Adonis L. and their extracts have been widely used clinically in some countries, including the use of $A$. vernalis and A. amurensis in Russia and China. To provide a comprehensive review, the information on this genus was gathered via the internet and libraries, and the search languages were set to English and Chinese. The native languages of some articles (written in Bulgarian, Russian and German) as well as other factors including older publication dates and the absence of an English abstract made it impossible for us to cite and understand some articles. Although the pharmacological effects of this plant were widely studied in Russia before 1950s, much of the relevant literature is hard to access (Shikov et al., 2014). As a result, some older studies published in various languages were not included in this review and should be examined and reviewed further. Recently, the review of botany, traditional use, phytomedicine, pharmacology and toxicity of 
A. vernalis provides comprehensively information for this plant used in Europe (Latté, 2018).

According to the website www.theplantlist.org, 32 species from the genus were accepted as native to Europe and Asia. However, with the exception of A. vernalis, A. aestivalis, and A. amurensis, the phytochemistry and the modern pharmacology of most of the species have not been investigated comprehensively and clinically validated. Although A. vernalis has been become a well-known herbal medicine for cardioprotection, especially in Russia, Bulgaria, etc. (Popiliev et al., 1973; Sorokina, 1989; Wichtl, 1990), only small numbers of in vitro and in vivo studies on their cardioprotective effects are available (Popiliev et al., 1973). Considering that some clinical studies assayed about 50 years old are not valid anymore, the development of this genus should be paid more attention.

To date, more than 120 chemical components have been isolated and identified from the genus Adonis. With the exception of the cardiac glycosides, some well-known flavones in the genus also were isolated and identified with the wide pharmacological activities, including antioxidant, anti-microbial, anti-inflammatory, cardioprotective, neuroprotective, and anti-allergic properties, and these compounds should be paid more attention (George et al., 2017; Aziz et al., 2018; Guo et al., 2018; Kim et al., 2018).

Additionally, $A$. vernalis is a medicinal plant whose above-ground parts at the flowering or fruiting stages are harvested from the wild as a raw material for the pharmaceutical industry in China. In the past century, with the abundant use of A. vernalis as well as a lack of xerothermic habitats and slow plant growth among others, this resource has rapidly decreased and is close to extinction (Lange, 2000; Baier and Tischew, 2004;

\section{REFERENCES}

Abduchamidov, V. N., Hammermann, A., and Sokolov, W. (1971). Adonis turkestanicus-eine neue aussichtsreiche Herz- und Gefasswirksame Heilpflanze. Planta Med. 20, 272-277. doi: 10.1055/s-0028-1099704

Aitova, R. Z., Maslennikova, V. A., Yamatova, R. S., Gorovits, M. B., and Abubakirov, N. K. (1971). Adonis glycosides III. Adonylic Acid. Khim. Prir. Soedin. 6, 847-848.

Aziz, N., Kim, M. Y., and Cho, J. Y. (2018). Anti-inflammatory effects of luteolin: a review of in vitro, in vivo, and in silico studies. J. Ethnopharmacol. 225, 342-358. doi: 10.1016/j.jep.2018.05.019

Bae, K. H. (2000). The Medicinal Plants of Korea. Seoul: Kyo-Hak Publishing Co, 128.

Bae, K. H., You, Y. J., Park, J. Y., An, R. B., Kim, Y. H., Kang, J. S., et al. (2000). Screening of angiogenesis inhibitors from Korean plants (I). Kor. J. Pharmacol. 31, 320-324.

Baek, Y. S., Jung, J. W., Lee, S. H., Baek, N. I., and Park, J. H. (2015). A new pregnane hexaglycoside from Adonis multiflora. J. Korean Soc. Appl. Biol. Chem. 58, 895-899. doi: 10.1007/s13765-015-0120-0

Baier, A., and Tischew, S. (2004). Nature conservation management on dry grassland sites in Sachsen-Anhalt-Investigation on threatening factors and development strategies in the nature reserve "Lämmerberg und Vockenwinkel". Hercynia 37, 201-230.

Bekhterev, V. M. (1898). The importance of a mixture of Adonis vernalis or digitalis with bromides or codeine in the treatment of epilepsy. Rev. Psychiatry 9:679.

Benson, W. M., and Edwards, L. D. (1941). The utilization of pigeons for the biological assay of Adonis vernalis, N.F. VI. presented to the scientific section of the A. PH. A., detroit meeting. J. Am. Pharm. Assoc. 31, 49-51. doi: 10.1002/ jps.3030310206
Denisow et al., 2014). Meanwhile, owing to the weak germination of the seeds and the slow growth intensity of the plants, the cultivation is unsuccessful (Galambosi, 1980a,b). Since 1982, it has been protected in several countries and the trade of this plant was banned in many East European countries (Lange, 2000). Therefore, investigation of sustainable usage practices is still necessary. This introduces the urgent problem of cultivation on a commercial scale, which would be useful for its conservation (Poluyanova and Lyubarskii, 2008).

In short, the phytochemical and pharmacological studies of the genus Adonis L. have received much interest. Extracts enriched in cardiac glycosides have been developed, and active compounds have been isolated and proven to provide cardioprotective activity. However, plants of this genus should be studied and developed further, with particular attention paid to conservation of resources and clinical testing.

\section{AUTHOR CONTRIBUTIONS}

$\mathrm{XS}$ and $\mathrm{JZ}$ conceived the review. $\mathrm{XS}, \mathrm{XG}, \mathrm{XM}, \mathrm{YZ}$, and $\mathrm{BL}$ wrote the manuscript. FY, HP, WW, and $\mathrm{CW}$ collected the literatures. YZ and CW edited the manuscript. All authors read and approved the final version of the manuscript.

\section{FUNDING}

This work was financed by the National Natural Science Foundation of China (31772790 and 31302136), and Key Technology R\&D Program of Gansu Province (2016GS10130).

Büchner, S. H., Kikuchi, K., and Chen, K. K. (1965). A new glycoside of Adonis vernalis. Life Sci. 4, 37-39. doi: 10.1016/0024-3205(65)90029-9

Budzianowski, J., Pakulski, G., and Robak, J. (1991). Studies on antioxidative activity of come c-glycosyl flavones. Pol. J. Pharmacol. Pharm. 43, 395-401.

Burrows, G. E., and Tyrl, R. J. (2001). Adonis L. In: Toxic Plants of North America. Ames. IA: Iowa State University Press, 1006-1007.

Catalogue of Life (2017). Adonis Flammea Jacq. Available at:http://www.catalogueoflife.org/col/details/species/id/ f572e94c982ad9cb96c6e67bdad5dc56. Retrieved 2017-04-21

Chen, K. K., and Anderson, R. C. (1947). Digitalis-like action of some new glycosides and esters of strophanthidin. J. Pharmacol. Exper. Therap. 90, 271-275.

Chen, K. K., Brown Robbins, E., and Bliss, C. I. (1942). The digitalis-like principles of calotropis compared with other cardiac substances. J. Pharmacol. Exper. Therap. 74, 223-234.

Chen, K. K., Hendernson, F. G., and Anderson, R. C. (1951). Comparison of forty-two cardiac glycosides and aglycones. J. Pharmacol. Exp. Ther. 103, $420-430$.

Chernobai, V. T., Komissarenko, N. F., and Litvinenko, V. I. (1968). Structure of flavonoid glycoside from Adnois vernalis. Khim. Prir. Soedin. 4:51. doi: 10.1007/ s12272-012-0303-8

Chi, L. G., Chen, Y., Zhou, M., Yu, X. F., and Chen, Z. (1985). The cardiotonic effects of the total glycosides of Adonis pseudoamurensis. Trad. Chin. Drug Res. Clin. 1:214.

Chiang, T. J., and Mi, C. S. (1958). A pharmacological study of FU Shou-Tsao herba Adnonis amurensis. Acta Pharm. Sin. 6, 323-336.

Chinese Materia Editorial Committee, and State Chinese Medicine Administration Bureau (2002). Chinese Materia, Tibetan Volume. Shanghai: Shanghai Scientific and Technical Publishers. 
Committee for the Pharmacopoeia of P. R. China (1975). Pharmacopoeia of P.R. China. China: China Medical Science and Technology Press.

Coronary Disease Control Group of Liaoning TCM College's Hospital (1971). The clinic observation of Adonis amurensis treating heart failure of 47 cases. Liaoning. Med. 5:44.

Dai, Y., Zhang, B. B., Xu, Y., and Liao, Z. X. (2010). Chemical constituents of Adonis coerulea Maxim. Nat. Prod. Res. Dev. 22, 594-596.

Das, H., Raghav, S., Gupta, B., and Das, R. H. (2007). Anti-inflammatory compounds from medicinal plant Ruta graveolens. Acta Horticult. 756, 389-398. doi: 10.1007/s11626-014-9813-7

Davies, R. L., and Whyte, P. B. (1989). Adonis microcarpa (pheasant's eye) toxicity in pigs fed field pea screenings. Aust. Vet. J. 66, 141-143. doi: 10.1111/j.17510813.1989.tb09780.x

Degen, A. V. (1932). Adonis-vergiftung. Fortschr. Landwirtsch. 7:556.

Deng, S. X., Li, C. D., and He, G. P. (1963). The cardiotonic effect of the total glycosides of Adonis brevistyla Franch. Acta Pharm. Sin. 10:677.

Denisow, B., Wrzesie, M., and Cwener, A. (2014). Pollination and floral biology of Adonis vernalis L. (Ranunculaceae) -a case study of threatened species. Acta Soc. Bot. Pol. 83, 29-37. doi: 10.5586/asbp.2014.001

Dong, Y. (1981). The effect of the total cardiac glycosides treating premature ventricular contraction. Fujian Med. 1:48.

Drozd, G. A., Koreshchuk, K. E., Khapugina, L. L., and Miroshnikov, E. V. (1971). Vitexin-a new flavone glycoside of Adonis vernalis. Khim. Prir. Soedin. 4, 526-527. doi: 10.1007/BF00564759

Egger, K. (1965). Die ketocarotinoide in Adonis annua L. Phytochemistry 4, 609-618. doi: 10.1016/S0031-9422(00)86223-8

Egger, K., and Kleinig, H. (1967a). Die ketocarotinoide in Adonis annua L.-II.: zur struktur der ester. Phytochemistry 6, 437-440. doi: 10.1016/S0031-9422(00) 86302-5

Egger, K., and Kleinig, H. (1967b). Die ketocartinoide in Adonis annua L.-III: vergleich mit synthetischen substanzen. Phytochemistry 6, 903-905. doi: 10. 1016/S0031-9422(00)86040-9

Evdokimov, P. K. (1979). Composition of Adonis leiosepala. Khim. Prir. Soedin. 5:736.

Felter, H. W., and Lloyd, J. U. (2006). Adonis-Pheasant's Eye. King's American Dispensatory. Available at: http://www.ibiblio.org/herbmed/eclectic/kings/ adonis.htmL

Flora of China (2018). Available at: http://www.efloras.org/florataxon.aspx?flora id=2\&taxon_id=100626

Franz, G. (1971). Studies on the methylation of cymarose in Adonis vernalis. Phytochemistry 10, 3001-3003. doi: 10.1016/S0031-9422(00)97342-4

Galambosi, B. (1980a). Results and cultivation of some wildflower medicinal plants in the "Szilasmenti" cooperative. Acta Hort. 96, 343-352. doi: 10.17660/ ActaHortic.1980.96.37

Galambosi, B. (1980b). Termesztési tapasztalatok magról vetett Adonis vernalis L. növényekkel. Botanikai Közlemények. 67, 307-311.

Galey, F. D., Holstege, D. M., PlumLee, K. H., Tor, E., Johnson, B., Anderson, M. L., et al. (1996). Diagnosis of oleander poisoning in livestock. J. Vet. Diagn. Invest. 8, 358-364. doi: 10.1177/104063879600800314

Genkina, G. L., Éidler, Y. I., Shakirov, T. T., and Yamatova, R. S. (1972). Spectrophotometric determination of the cardenolides in the epigeal part of Adonis chrysocyathus. Khim. Prir. Soedin. 6, 747-749. doi: 10.1007/BF00564595

George, V. C., Dellaire, G., and Rupasinghe, H. P. V. (2017). Plant flavonoids in cancer chemoprevention: role in genome stability. J. Nutrit. Biochem. 45, 1-14. doi: 10.1016/j.jnutbio.2016.11.007

Ghorbani, N. M., Azizian, D., Sheidai, M., and Khatamsaz, M. (2008). Pollen morphology of some Adonis L. species (Ranunculaceae) from Iran. Iran. J. Bot. $14,165-170$.

Gostin, I. N. (2011). Anatomical and micromorphological peculiarities of Adonis vernalis L. (Ranunculaceae). Pak. J. Bot. 43, 811-820.

Greeff, K., and Kasperat, H. (1961). Konvulsive und paralytische wirkungen von digitalis-glykosiden und geninen bei intracerebraler und intravenoser injektion an mausen (convulsive and paralytic effects of digitalis glycosides and genins after intracerebral and intravenous injection in mice). Arzeimittelforschung 11, 908-909.

Gu, P. K., Zhang, Y., Chen, Y. L., Shang, M., and Jin, Z. J. (1981). The electrophysiology effect of Xinfugan on heart muscle cells. J. Shanghai Sec. Med. Univ. 2:10.
Gu, X. L., Feng, S. X., Ma, B. R., and Shi, Y. (1989). Isolation and determination of some cardiac glycosides from Adonis pseudoamurensis by high-performance liquid chromatography. Appl. Mod. Med. 6, 1-4.

Gu, X. L., Ma, B. R., and Ren, X. G. (1990). Separation and determination of relative content of cardiac glycosides from Adonis amurensis with high-performance liquid chromatography. J. Notman Bethune Univ. Med. Sci. 16, 131-135.

Gu, Z. L., Qian, Z. N., Zang, Y. Y., Chen, B. Q., and Wang, Y. Q. (1980). The pharmacology of the total glycosides of Adonis amurensis. The effects of the total glycosides on the central nervous system of rabbits. Zhong Cheng Yao Yan Јіи $3,40-43$.

Guo, D., Hu, X., Zhang, H., Lu, C., Cui, G., and Luo, X. (2018). Orientin and neuropathic pain in rats with spinal nerve ligation. Int. Immunopharmacol. 58, 72-79. doi: 10.1016/j.intimp.2018.03.013

Heyl, F. W., Hart, M. C., and Schmidt, J. M. (1918). An examination of the leaves of Adonis vernalis. J. Am. Chem. Soc. 2, 436-453. doi: 10.1021/ja02235a 018

Heyn, C. C., and Pazy, B. (1989). The annual species of Adonis (Ranunculaceae)-A polyploid complexit. Plant Sys. Evol. 168, 181-193. doi: 10.1007/bf00936098

Hirsch, H., Wagner, V., Danihelka, J., Ruprecht, E., Sánchez-Gomez, P., Seifert, M., et al. (2015). High genetic diversity declines towards the geographic range periphery of Adonis vernalis, a eurasian dry grassland plant. Plant Biol. 17, 1233-1241. doi: 10.1111/plb.12362

Hurst, E. (1942). Family Ranunculaceae. The Poison Plants of New South Wales. Sydney: The Snelling Printing Works PTY. Ltd, 113-114.

Junior, P., and Wichtl, M. (1980). 3-epi-periplogenin: ein neues cardenolid aus Adonis vernalis. Phytochemistry 19, 2193-2197. doi: 10.1016/S0031-9422(00) 82222-0

Kamata, T., and Simpson, K. (1987). Study of astaxthin diester extracted from Adonis aestivealis. Comp. Biochem. Physiol. 86B, 587-591.

Katz, A., and Reichstein, T. (1947). Glykoside und aglykone; adonitoxin, das zweite stark herzwirksame Glykosid aus Adonis vernalis. Pharm. Acta. Helv. 22, 437-459.

Keshan Research Group of Jilin Medical University, First Clinical College, Second Clinical College, Third Clinical College of Jilin Medical University (1977). The clinical application of Binglianghua (Adonis amurensis). Jilin Med. Univ. 4, $42-53$.

Kim, S. J., Pham, T. H., Bak, Y., Ryu, H. W., Oh, S. R., and Yoon, D. Y. (2018). Orientin inhibits invasion by suppressing MMP-9 and IL-8 expression via the PKC/ ERK/AP-1/STAT3-mediated signaling pathways in TPA-treated MCF7 breast cancer cells. Phytomedicine 50, 35-42. doi: 10.1016/j.phymed.2018. 09.172

Kloot, P. M. (1976). The species of Adonis naturalized in Australia. Muelleria 3, 300-207.

Komissarenko, N. F., Korzennikova, ÉP., and Lushpa, O. U. (1977). A chemical study of Adonis tianschanicus. Khim. Prir. Soedin. 2, 287-288. doi: 10.1007/ BF00563973

Komissarenko, N. F., Korzennikova, É. P., and Yatsyuk, Ya (1973a). Cardenolides of Adonis wolgensis. Khim. Prir. Soedin. 6, 806-807. doi: 10.1007/BF00 565712

Komissarenko, N. F., Korzennikova, P., and Yatsyuk, V. Ya (1973b). Cardenolides of Adonis wolgensis. Khim. Prir. Soedin. 9:433. doi: 10.1007/BF00565712

Komissarenko, N. F., Yatsyuk, Ya, and Korzennikova, P. (1973c). Flavonoids of Adonis wolgensis. Khim. Prir. Soedin. 3:439. doi: 10.1007/BF00565720

Kooti, W., Hasanzadeh-Noohi, Z., Sharafi-Ahvazi, N., Asadi-Samani, M., and Ashtary-Larky, D. (2016). Phytochemistry, pharmacology, and therapeutic uses of black seed (Nigella sativa). Chin. J. Nat. Med. 14, 0732-0745. doi: 10.1016/ S1875-5364(16)30088-7

Kooti, W., Moradi, M., Peyro, K., Sharghi, M., Alamiri, F., Azami, M., et al. (2018). The effect of celery (Apium graveolens L.) on fertility: a systematic review. J. Complement. Integ. Med. 15:20160141. doi: 10.1515/jcim-20160141

Kopp, B., Krenn, L., Kubelka, E., and Kubelka, W. (1992). Cardenolides from Adonis aestivalis. Phytochemistry 31, 3195-3198. doi: 10.1016/0031-9422(92) 83473-C

Kovaříková, A., and Chen, K. K. (1965). Activities of newer glycosides of Adonis vernalis L. Life Sci. 4, 41-43. doi: 10.1016/0024-3205(65)90030-5

Kubo, S., Kuroda, M., Matsuo, Y., Masatani, D., Sakagami, H., and Mimaki, Y. (2012). New cardenolides from the seeds of Adonis aestivalis. Chem. Pharm. Bull. 60, 1275-1282. doi: 10.1248/cpb.c12-00489 
Kubo, S., Kuroda, M., Yokosuka, A., Sakagami, H., and Mimaki, Y. (2015). Amurensiosides L-P, five new cardenolide glycosides from the roots of Adonis amurensis. Nat. Prod. Commun. 10, 27-32.

Kummer, D. H. (1952). Vergiftungen bei pferden durch Adonis in luzerneheu (poisonings in horses with Adonis-contaminated alfalfa hay). Tierarztl. Umsch. 7, 430-431.

Kuo, C. H., Chang, C. H., Sun, C. H., Han, H., Chin, E. P., and Chiang, M. Y. (1962). A pharmacological study of Adonis amurensis. Acta Pharm. Sin. 9, 135-144.

Kuroda, M., Kubo, S., Uchida, S., Sakagami, H., and Mimaki, Y. (2010). Amurensiosides A-K, 11 new pregnane glycosides from the roots of Adonis amurensis. Steroids 75, 83-94. doi: 10.1016/j.steroids.2009.10.008

Lamzhav, A. (1975). Untersuchungen Ueber das Vorkommen Von Herzwirksamen Glycosiden und Flavonoiden in Adonis Mongolica Sim. Dissertation a. section biowissenschaften der karl marx universität. Leipzig.

Lamzhav, A. (1983). Coumarins of Adonis mongolica. Khim. Prir. Soedin. 3:402.

Lange, D. (2000). Conservation and Sustainable use of Adonis vernalis, A Medicinal Plant in International Trade. Rome: Food and Agriculture Organization of the United Nations.

Lateef, T., Riaz, A., Zehra, A., and Qureshi, S. A. (2012). Antihyperlipidemic effect of Adonis vernalis. J. Dow Univ. Health Sci. 6, 47-51.

Latté, K. P. (2018). Adonis vernalis L. das frühlingsadonisröschen. Z. Phytother. 39, 45-51. doi: 10.1055/s-0044-100153

Lazareva, D. N. (1975). Effect of methyluracil on the sensitivity of animals to cardiac glycosides and on the coronary blood flow. Farmakol. Toksikol. 38, 311-313.

Lee, J. H., Lee, S. T., Seo, Y. B., Yeo, S. H., and Lee, N. S. (2003). A morphological reexamination on the genus Adonis L. sensu lato (Ranunculaceae) in Korea. Korean J. Plant. Taxon. 33, 435-454. doi: 10.11110/kjpt.2003.33.4.435

Lehmann, H. D. (1984). Zur wirkung pflanzlicher glykoside auf widerstandsgefäße und kapazitätsgefäße. Arzneimittelforschung 34, 423-429.

Lenel-Pekelis. (1949). Bio-assay of Adonis vernalis glycosides: mercier, f: cardiologia. Am. Heart J. 37:314. doi: 10.1016/0002-8703(49)90602-X

Liu, J., and Cui, X. W. (2007). Determination of convallatoxin from Adonis amurensis by high-performance liquid chromatography. Chin. Trad. Herb. Drug 38, 617-618

Ma, B. R., Zhao, Q. C., Yang, S. J., and He, L. (1985). A preliminary study on the chemical components of Adonis pseudoamurensis W.T.Wang. J. Norman Bethune Health Sci. Univ. 11:371.

Maham, M., and Sarrafzadeh-Rezaei, F. (2014). Cardiovascular effects of Adonis aestivalis in anesthetized sheep. Vet. Res. Forum. 5, 193-199.

Maiden, J. H. (1912). A new poison plant (Adonis autumnalis). Agri. Gaz. New South Wales 23:810.

Mathe, A., and Mathe, J. I. (1979a). Data to the cardiac glycoside content of Adonis vernalis L. in Hungary. Herb. Hung. 18, 115-124.

Mathe, A., and Mathe, J. I. (1979b). Preliminary survey of the variability of the cardiac glycoside production of Adonis vernalis L. native in Hungary. Herb. Hung. 18, 21-28.

Matthiesen, U., Pauli, G. F., and Junior, P. (1992). Aleppotrioloside, an aliphatic alcohol glycoside from Adonis aleppica. Phytochemistry 31, 2522-2524. doi: 10.1016/0031-9422(92)83314-O

May, G., and Willuhn, G. (1978). Antiviral activity of aqueous extracts from medicinal plants in tissue cultures. Arzneimittel Forschung 28, 1-7.

Mohadjerani, M., Tavakoli, R., and Hosseinzadeh, R. (2014). Fatty acid composition, antioxidant and antibacterial activities of Adonis wolgensis $\mathrm{L}$. extract. Avicenna J. Phytomed. 4, 24-30.

Munch, J. C., and Jr Krantz, J. C. (1934). Pharmacological and chemical studies of the digitalis group. I. Adonis, apocynum and convallaria. J. Am. Pharm. Assoc. XXIII:988.

Nosal, M. A., and Nosal, I. M. (1960). Lekarstvennuiye Rasteniyai Sposobuiikh Primrniyav Narodye (Medicinal Plants and the Ways that they are used by people). Kievp: State medical publishing, 256.

Orhan, I. E., Gokbulut, A., and Senol, F. S. (2017). Adonis, sp., Convallaria sp., Strophanthus sp., Thevetia sp., and Leonurus sp. -cardiotonic plants with known traditional use and a few preclinical and clinical studies. Curr. Pharm. Design. 23, 1051-1059. doi: 10.2174/1381612822666161010 104548

Pauli, G. F. (1995). Adoligoses, oligosaccharides of rare sugars from Adonis aleppica. J. Nat. Prod. 58, 483-494. doi: 10.1021/np50118a002
Pauli, G. F., and Junior, P. (1993). Alepposides, cardenolide oligoglycosides from Adonis aleppica. J. Nat. Prod. 56, 67-75. doi: 10.1021/np50091a010

Peter, J., and Max, W. (1980). 3-epi-periplogenin: ein neues cardenolid aus Adonis vernalis. Phytochem 19, 2193-2197. doi: 10.1016/S0031-9422(00)82222-0

Pitra, J., and Čekan, Z. (1961). Herzwirksame glykoside III. Cardenolide des adonisröschens (Adonis vernalis L.). Coll. Czech. Chem. Commun. 26, 1551-1558. doi: 10.1135/cccc19611551

Poláková, A., and Čekan, Z. (1965). Isolation and structure of cardenolides from Adonis vernalis. Cesk. Farm. 14, 307-315.

Poluyanova, V. I., and Lyubarskii, E. L. (2008). On the ecology of seed germination in Adonis vernalis. Russian J. Eco. 39, 68-69. doi: 10.1134/S1067413608010116

Ponomarenko, A. A., Komissarenko, N. F., and Stukkei, K. L. (1971a). Cardenolides from Adonis amurensis. Khim. Prir. Soedin. 7, 848-849.

Ponomarenko, A. A., Komissarenko, N. F., and Stukkei, K. L. (1971b). Coumarins from Adonis amurensis. Khim. Prir. Soedin. 5, 661-662.

Popiliev, I., Belovejdov, N., and Gelinov, H. (1973). Clinical therapeutic studies with the cardiotonic preparation AV 2 (Adonis vernalis glycosides). Savremenna Med. 24, 29-31.

Qin, Y. (2000). Ethanol extract of Adonis amurensis Regel et Radde's influence on the rabbit's movement of atrial muscle in vitro. J. Tonghua Teach. Coll. 5:49.

Renstrøm, B., Berger, H., and Liaaen-Jensen, S. (1981). Esterified, optical pure (3S, 3'S)-astaxanthin from flowers of Adonis annua. Biochem. Sys. Eco. 9, 249-250. doi: 10.1016/0305-1978(81)90003-X

Sato, Y., Hirano, M., Nitta, I., Azuma, J., Hayashi, K., and Mitsuhashi, H. (1971). Components of adonis plants. Chem. Pharm. Bull. 19, 202-205. doi: 10.1248/ cpb.19.202

Shang, X. F., Guo, X., Yang, F., Li, B., Pan, H., Miao, X. L., et al. (2017). The toxicity and the acaricidal mechanism against Psoroptes cuniculi of the methanol extract of Adonis coerulea Maxim. Vet. Parasitol. 240, 17-23. doi: 10.1016/j.vetpar.2017. 04.019

Shang, X. F., Miao, X. L., Wang, D. S., Li, J. X., Wang, X. Z., Yan, Z. T., et al. (2013). Acaricidal activity of extracts from Adonis coerulea maxim. against Psoroptes cuniculi in vitro and in vivo. Vet. Parasitol. 195, 136-141. doi: 10.1016/j.vetpar. 2012.12.057

Shang, X. F., Tao, C. X., Miao, X. L., Wang, D. S., Tangmuke, Dawa, et al. (2012). Ethno-veterinary survey of medicinal plants in Ruoergai region. Sichuan province, China. J. Ethnopharmacol. 142, 390-400. doi: 10.1016/j.jep.2012. 05.006

Shen, X. T., Qian, Y. X., Wang, S. B., Lin, J. B., Ding, J. M., and Yang, Z. C. (1983). Action of k-strophanthin or Adonside with antiarrhythmic drugs on aconitine induced cardiac arrhythmia in mice. Acta Acad. Med. Primae Shanghai. 10, 41-46.

Shi, L., Wang, D. S., Gu, X. H., and Pan, J. X. (1979). The pharmacology of the total glycosides of Adonis amurensis. I The effects of the total glycosides on the functions of the left ventricle and $\mathrm{K}+$ metabolism of myocardium. ZhongChengYao YanJiu 4, 27-32.

Shikov, A. N., Pozharitskaya, O. N., Makarov, V. G., Wagner, H., Verpoorte, R., and Heinrich, M. (2014). Medicinal plants of the Russian pharmacopoeia; their history and applications. J. Ethnopharmacol. 154, 481-536. doi: 10.1016/j.jep. 2014.04.007

Shimizu, Y., Sato, Y., and Mitsuhashi, H. (1967). Isolation and structure of adonilide. Chem. Pharm. Bull. 15, 2005-2006.

Shimizu, Y., Sato, Y., and Mitsuhashi, H. (1969a). Isolation and characterization of fukujusonorone, an 18-norpregnane derivative from Adonis amurensis Regel et Radd. Experientia 25, 1129-1130. doi: 10.1007/BF01900226

Shimizu, Y., Sato, Y., and Mitsuhashi, H. (1969b). Isolation and structures of new pregnane derivatives from Adonis amurensis. Chem. Pharm. Bull. 17, 2391-2394. doi: 10.1248/cpb.17.2391

Shimizu, Y., Sato, Y., and Mitsuhashi, H. (1978). A study of the chemical constituents of Adonis amurensis. Lloydia 41, 1-16.

Shuguang Medical Team of Anshan City, Department of Pharmacy of Anshan Steel Hospital, and Department of Pharmacy of Anshan Medical School (1973). The electrocardiogram of cats treated by the total glycosides of Adonis amurensis. Xin Yiyao Xue Zazhi 10:24.

Sokolov, Ya (2000). Phytotherapy and Phytopharmacology: The Manual for Doctors. Moscow: Medical News Agency.

Sorokina, A. A. (1989). Spring adonis (Adonis vernalis L.). Med. Sestra 48, 43-45. 
Sun, W. (1988). The poisoning case induced by Adonis amurensis. Chin. J. Hospit. Pharm. 8:38

The plant list (2013). Available at: http://www.theplantlist.org/1.1/browse/A/ Ranunculaceae/Adonis/

Thieme, H., and Lamzhav, A. (1976). Ueber die cardenolidglycoside von Adonis mongolica Sim. Pharmazie 25:1976.

Turova, A. D., and Sapozhnikova, E. N. (1989). Medicinal Plants of USSR and their applications. Moscow: WHO.

Utkin, L. A. (1931). Traditional medicinal plants of siberia. Proc. Sci. Res. Institutes Ind. 434:24.

Vogel, V. G., and Kluge, E. (1961). Comparative studies on the diuretic action of some steroids with cardiac action. Arzneimittelforschung 11, $848-850$.

Wagler, M. (2001). The homeopathic pharmacopoeia 2001: new regulations for homeopathic drugs. Deutsche Apothr. Zeit. 141, 86-89.

Wagner, H., Rosprim, L., and Galle, K. (1975). Endgültige struktur von adonivernith aus Adonis vernalis. Phytochemistry 14, 1089-1091. doi: 10.1016/ 0031-9422(75)85193-4

Wang, D., Liu, L. J., Liu, M., Li, R. J., and Liu, M. Y. (1991). The change regulation of total cardiac glycoside at the different phase of Adonis amurensis Regel et Radde. Chin. Trad. Herb. Drugs 14:7.

Wang, D. S., Zhou, Z. Q., Wang, S. L., Wang, X. Y., and Gu, X. T. (1981). The pharmacology of the total glycosides of Adonis amurensis. III The diuretic effects of the total glycosides and the relationship between the effects and ion in urine. ZhongChengYao Yanjiu 5, 35-36.

Wang, M. X., and Feng, W. X. (1982). The abnormal of heart rate induced by Adonis amurensis. Chin. J. Pract. Intern. Med. 2:50.

Wichtl, M. (1990). Herbal medicines in cardiovascular disorders. Deutsche Apoth. Zeit 130, 1251-1256.

Wichtl, M., Jentzsch, K., and Türk, E. (1972). Strophantidine fucoside, a new cardenolide glycoside from Adonis vernalis L. Monatsh. Chem. 103, 889-895. doi: 10.1007/BF00905451

Winkler, C., and Wichtl, M. (1985). New cardiac glycosides from Adonis vernalis. Pharm. Acta Helv. 60, 243-247.

Winkler, C., and Wichtl, M. (1986). Neue cardenolide aus Adonis vernalis. Planta Med. 52:68. doi: 10.1055/s-2007-969076

Woods, L. W., Filigenzi, M. S., Booth, M. C., Rodger, L. D., Amold, J. S., and Puschner, B. (2004). Summer pheasant's eye (Adonis aestivalis) poisoning in three horses. Vet. Pathol. 41, 215-220. doi: 10.1354/vp.413-215
Woods, L. W., George, L. W., Anderson, M. L., Woods, D. M., Filigenzi, M. S., and Puschner, B. (2007). Evaluation of the toxicity of Adonis aestivalis in calves. J. Vet. Diagn. Invest. 19, 581-585. doi: 10.1177/104063870701900523

Woods, L. W., Puschner, B., Filigenzi, M. S., Woods, D. M., and George, L. W. (2011). Evaluation of the toxicity of Adonis aestivalis in sheep. Vet. Rec. 168:49. doi: 10.1136/vr.c6231

Yang, W. H., Zhang, X. W., Xu, W. J., Huang, H. Y., Ma, Y., Bai, H., et al. (2015). Overview of pharmacological research on Adonis L. Agri. Sci. Tech. 16, 626-628.

Yatsyuk, V. Y., Dolya, V. S., and Gella, V. (1983). A phytochemical investigation of the epigeal part of Adonis aestivalis. Khim. Prir. Soedin. 5:641.

Yatsyuk, V. Y., Komissarenko, N. F., and Gella, ÉV. (1976). Cardenoloids of Adonis wolgensis. Khim. Prir. Soedin. 5:672. doi: 10.1007/BF00565218

Yin, L., Zhang, Y., Tian, H. Y., and Jiang, R. W. (2014). Chemical constituents from Adonis amurensis. Chin. Trad. Herb. Drugs 45:3361.

You, Y.-J., Yong, K., Nguyen-Hai, N., and Byung-Zun, A. (2003). Inhibitory effect of Adonis amurensis components on tube-like formation of human umbilical venous cells. Phytother. Res. 17, 568-570. doi: 10.1002/ptr. 1184

Zhang, H. D., Zhang, S. J., and Chen, Y. Z. (1991). Studies on chemical constituents of Adonis coerulea maxim-a tibetan medicinal herb. J. Lanzhou Univ. 27, 88-92.

Zhang, L. H., Peng, Y. J., Xu, X. D., Wang, S. N., Yu, L. M., Hong, Y. M., et al. (2015). Determination of other related carotenoids substances in astaxanthin crystals extracted from Adonis amurensis. J. Oleo Sci. 64, 751-759. doi: 10.5650/ jos.ess 14203

Zhang, X. E. (1999). Two cases of abnormal heart rate induced by Adonis amurensis. J. Electrocard. 18:53.

Zheng, H. C. (1975). Translated from makciotoba C., 1975. Pactè Pecyp 11:512.

Conflict of Interest Statement: The authors declare that the research was conducted in the absence of any commercial or financial relationships that could be construed as a potential conflict of interest.

Copyright (c) 2019 Shang, Miao, Yang, Wang, Li, Wang, Pan, Guo, Zhang and Zhang. This is an open-access article distributed under the terms of the Creative Commons Attribution License (CC BY). The use, distribution or reproduction in other forums is permitted, provided the original author(s) and the copyright owner(s) are credited and that the original publication in this journal is cited, in accordance with accepted academic practice. No use, distribution or reproduction is permitted which does not comply with these terms. 